\title{
CONTROLES PREVENTIVOS Y REPARADORES DE LA CONSTITUCIONALIDAD INTRINSECA DE LOS TRATADOS INTERNACIONALES
}

\author{
POR \\ ANTONIO REMIRO BROTONS \\ Universidad Autónoma de Madrid
}

\begin{abstract}
SUMARIO
I. LA CONSTITUCIONALIDAD INTRÍNSECA O MATERIAL DE LOS TRATADOS INTERNACIONALES: 1. Consideraciones generales. 2. Derecho español.-II. Los CONTROLES DE LA CONSTITUCIONALIDAD DE LOS TRATADOS INTERNACIONALES: 1. Consideraciones generales. 2. Derecho español: antecedentes.-III. Los CONTROLES PREVENTIVOS DE LA CONSTTTUCIONALIDAD DE LOS TRATADOS INTERNACIONALES EN EL DeRECHO ESPAÑOL vigente: 1 . El control de la constitucionalidad de los tratados previsto por el artículo 95.2 de la Constitución. 2. El control de la constitucionalidad de las leyes orgánicas de autorización de la celebración de tratados contemplados por el artículo 93 de la Constitución.-IV. LOS CONTROLES REPARADORES DE LA CONSTITUCIONALIDAD DE LOS TRATADOS INTERNACIONALES EN EL DERECHO ESPAÑOL VIGENTE: 1. En el proceso constituyente. 2. En la LOTC: recursos y cuestiones de constitucionalidad. 3. Aplicación a los tratados anteriores a la Constitución. 4. La sentencia desestimatoria y su eficacia preclusiva.
\end{abstract}

1. Se dice de un tratado, de alguna de sus cláusulas, que es material o intrínsecamente inconstitucional cuando su contenido choca o es incompatible con la Norma Fundamental del Estado. Hasta la Segunda Guerra Mundial, la cuestión de la constitucionalidad intrínseca de los tratados ha podido ser considerada como un problema esencialmente teórico ${ }^{1}$, pero hoy la apreciación ya no sería exacta. De una parte, los textos constitucionales, centrados tradicionalmente en la organización de los poderes del Estado, se han ido abriendo a la enumeración, definición y defensa de derechos y libertades individuales y colectivas, no sólo en el orden político, sino también en el económico, social o cultural, subrayando el carácter normativo y la aplicabilidad directa de sus preceptos. De otra parte, el Derecho internacional ha pasado de

${ }^{1}$ Véase $\mathrm{P}$. de Visscher, Les tendances internationales des Constitutions modernes, «Rec. des Cours de l'Académie de D. I.», I, 1952, pág. 545. 
regular la coexistencia entre Estados soberanos a propiciar su cooperación para la satisfacción de intereses comunes, la protección de los derechos humanos se ha convertido en uno de sus objetivos esenciales y la noción de que hay materias que corresponden a la competencia exclusiva de los Estados ha caído en bancarrota. Se han ampliado, en suma, los ámbitos en que Constitución y tratados pueden confluir con vocación operante y, por tanto, cooperar o... entrar en conflicto.

Desde una posición ortodoxa, ha de afirmarse que la Constitución delimita la libertad de compromiso del Estado en el orden internacional. Decir que el tratado podría prevalecer o desviarse de ella dañaría gravemente su postulado básico, la soberanía, y socavaría su condición de norma fundamental. Cuando una Constitución como la holandesa se manifestó dispuesta en 1953 a admitir excepciones a sus preceptos por vía convencional (art. 63), uno de sus comentaristas estimó que los Países Bajos se suicidaban como Estado soberano ${ }^{2}$. Más aún: algunas normas constitucionales enuncian prohibiciones y limitaciones específicas en la formación de los tratados. Así, por ejemplo, del artículo 13.3 de la Constitución española se deduce la prohibición de convenir con otro Estado la extradición por delitos políticos. La consecuencia es lógica: quien quiera concertar un tratado que escape al marco constitucional deberá antes revisar la Constitución, esto es, cambiar el marco.

Pero ¿no podemos acaso desafiar esta posición? ¿No cabe ser algo heterodoxo, discretamente desviacionista? ¿No abusan quienes hablan, sic et simpliciter, de la modificación de la Constitución por medio de los tratados? ¿Es que resulta de todo punto imposible que la ley fundamental del Estado permita, bajo ciertas condiciones, la estipulación de obligaciones internacionales que se aparten de sus normas? Quienes, desperezando su sentido crítico, participan de una actitud más abierta a la cooperación internacional, más dinámica, más internacionalista, han de sentirse tentados, hasta atrapados, por estas interrogantes. La posición tradicional, aducirán, llega a conclusiones demasiado netas, exageradas, porque carece de sensibilidad para advertir que, mientras la reforma constitucional tiene valor absoluto y alcance general, la admisión de un tratado cuyas cláusulas se separan de la Constitución tiene valor relativo y alcance particular; no pasa de ser la excepción a un precepto que conserva su vigencia; no persigue alterar definitivamente la ley fundamental sirviéndose del tratado, sino sólo flexibilizarla. La disponibilidad política de los gobiernos para concertar esta clase de tratados no será, desde luego, alta, pero no se trata de un supuesto de laboratorio y, en ciertas circunstancias, la satisfacción de señalados objetivos internacionales puede conducir a ellos. Habría de posibilitarse, pues, la conclusión de tales acuerdos sin que fuera necesaria la enmienda de la Constitución.

2. No es frecuente, ni mucho menos, que los textos constitucionales se pronuncien de esta manera. Ni siquiera que lo hagan expresamente sobre este punto, dando por supuesta la primacía de la Constitución. De ahí el mérito de los miembros de la ponencia que elaboró el anteproyecto de 5 de enero de 1978 al incluir una disposición según la cual «cuando un tratado sea con-

${ }^{2}$ H. F. v. Panhuys, The Netherlands Constitution and International Law, «Am. J. of I. Law», 1953, pág. 556. 
trario a la Constitución su conclusión deberá ser autorizada mediante el procedimiento previsto para la revisión constitucional» (art. 55.3) ${ }^{3}$. Movidos por la ilustración hecha acción de alguno de ellos, adoptaron un criterio progresivo moderado al proceder a su regulación: progresivo por cuanto admitían en principio las excepciones, por vía de tratado, a los preceptos constitucionales; moderado por cuanto tales excepciones se condicionaban siempre a la obtención de la autorización para la conclusión del tratado según el procedimiento de la reforma constitucional, especialmente lento y complejo en el anteproyecto del 5 de enero (arts. 157-159). Otras Constituciones más avanzadas, aun imponiendo un régimen de autorización más riguroso que el aplicable al común de los tratados cuya estipulación requiere la autorización parlamentaria, han prescindido del plus de solemnidad que suele acompañar al procedimiento de revisión o reforma constitucional y que, de un país a otro, puede implicar desde la consulta popular hasta una doble y sucesiva aprobación parlamentaria, enlazada por el puente de la disolución del Parlamento $y$ de las elecciones generales o ambas cosas a la vez ${ }^{4}$.

Por desgracia, los ponentes exhibieron una notable falta de convicción en la virtud de la fórmula sugerida. Tres meses después, aceptando una enmienda de la Minoría Catalana ${ }^{5}$, cambiaron radicalmente de rumbo $\mathrm{y}$, situándose en posición netamente conservadora, hicieron decir al anteproyecto del 17 de abril que la celebración de un tratado que contuviese estipulaciones contrarias a la Constitución requeriría, en todo caso, la previa revisión constitucional (art. 88). Nadie explicó el porqué de una rectificación que alineaba a nuestro texto constitucional con el francés de 1958 (art. 54) ${ }^{6}$, manifestación, según se advirtió en su día ${ }^{7}$ y luego ha sido recordado ${ }^{8}$, del reflejo nacionalista de sus principales redactores. A partir de ahí, un conformismo átono, ágrafo y generalizado permitió la consagración de esta posición —con ligeros ajustes de redacción - en el texto definitivo (art. 95.1) ${ }^{9}$.

${ }^{3}$ Este texto fue elaborado por los representantes de UCD, recogiendo la sugerencia hecha por el ponente socialista en la reunión de 11 de octubre de 1977. Su redacción es muy similar a la del artículo 31, pátrafo tercero, de la Constitución marroquí de 1972. Véase en «Bol. Leg. Ext.», vol. XXVIII, núm. 185.

"Véanse, por ejemplo, las Constituciones de Austria (art. 50.3), Holanda (art. 63), Islandia (art. 21) y República Federal de Alemania (art. 79.1). Las referencias a preceptos constitucionales de países europeos pueden consultarse en M. Daranas, Las Constituciones europeas, 2 t., Madrid, 1973.

${ }^{5}$ Enm. núm. 145 (Minoría Catalana). La enm. núm. 232 (H. Barrera) era del mismo tenor.

${ }^{6}$ En la doctrina francesa, Ch. Vallée, Note sur les dispositions relatives au Droit international dans quelques Constitutions récentes, «Ann. Fr. D. I.», 1979, págs, 270-272, ha puesto de relieve la relación entre la Constitución francesa y la española en este punto.

${ }_{7}$ N. Quoc Dinh, La Constitution de 1958 et le Droit international, «R. D. P.», 1959, página 515 .

${ }^{8} \mathrm{~F}$. Luchaire, Le contrôle de constitutionnalité des engagements internationaux et ses conséquences relatives a la Communauté européenne, «R. Trim. D. Eur.», pág. 392. Cl. Blumann, L'article 54 de la Constitution et le contrôle de constitutionnalité des traités en France, «R. Gén. D. I. P.», 1978, págs. 566 y sigs., ha insistido en que el art. 54 de la Constitución francesa constituye un obstáculo, un freno para el desarrollo del Derecho internacional.

${ }^{9}$ El texto propuesto por la ponencia fue aprobado sin debate tanto en Comisión $(6$ de junio de 1978, «D. de S.», núm. 81) como en el Pleno del Congreso (13 de julio, «D. de S.», 
La Constitución de 1978 es la primera de las españolas que regula expresamente la cuestión en que nos venimos demorando. Pero, desde una perspectiva internacional e internacionalista, la afirmación de que «la celebración de un tratado internacional que contenga estipulaciones contrarias a la Constitución exigirá la previa revisión constitucional» (art. 95.1) resulta poco imaginativa y ambiciosa. Hubiera sido preferible la omisión, un silencio que, más adelante, se pudiera romper, por vía interpretativa, en favor de la permisividad de tales tratados, observado, claro es, el procedimiento previsto en el Anteproyecto del 5 de enero. Pero el número 1 del artículo 95 parece cegar esa salida: si las estipulaciones de un tratado contrarían los preceptos constitucionales habrá que renunciar o corregir el tratado o, alternativamente, revisar la Constitución antes de que pueda entenderse su conclusión autorizada. Si no se desea lo uno ni lo otro, cabría aliviar el conflicto arropando la autorización parlamentaria de la prestación del consentimiento con las reservas adecuadas a las cláusulas convencionales que la Constitución no tolera, siempre y cuando las consienta el tratado ${ }^{10}$.

\section{II}

1. Sentado el principio de la conformidad de los tratados internacionales con la Constitución, hay que preguntarse si, y en qué medida, dispone el sistema de controles jurídicos adecuados y suficientes para verificar esa conformidad. Por supuesto que los órganos del Estado que participan del treaty-makingpower actúan con el propósito de respetar los preceptos constitucionales, pero si la presunción no es susceptible de contraste, si se rechaza la posibilidad de ponerla en entredicho ante un órgano con competencia para decidir, el tratado concluido y publicado habrá de ser aplicado. Sin un control eficaz, la denuncia de inconstitucionalidad navegará de lo académico a lo panfletario. Podrá ser un tierno cordero pascual testimonialmente inmolado por los sacerdotes de la doctrina, un arma arrojadiza en la arena política, un ardid en la controversia diplomática acerca de la nulidad del tratado en el orden internacional.

número 109). De las tres enmiendas que se formularon en la Cámara Alta, sólo una, de haber sido aprobada en sus mismos términos, hubiera restringido el alcance del principio ya adoptado. La enm. núm. 343 ( $\mathrm{L}$. Sánchez Agesta) - «La celebración de un tratado internacional, fuera del caso previsto en el art. 87 (vigente 93), que contenga estipulaciones contrarias a la Constitución, exigirá la previa revisión constitucional...»-implicaba, en efecto, tal vez más allá de la intención del enmendante, que no fundamentó su propuesta en este punto, la aceptación de que sin previa modificación de la ley fundamental se concluyesen tratados de transferencia a organizaciones internacionales del ejercicio de competencias derivadas de la Constitución que contuviesen estipulaciones contrarias a los preceptos constitucionales. La remisión al vigente art. 93 fue suprimida, con el consentimiento del enmendante, una vez que en Comisión Ballarín apuntó que «una técnica y una estética legislativa más perfecta es la que evita este tipo de remisiones». Esta apreciación es discutible. En cualquier caso, eliminada esta referencia, la redacción sugerida por Sánchez Agesta fue adoptada por la Comisión $(6$ de septiembre, $\ll D$. de $S . »$, núm. 50) y por el Pleno (30 de septiembre, «D. de S.», núm. 63) y fue, finalmente, la incorporada al texto constitucional.

${ }_{10}$ Así, por ejemplo, al adherirse España al Convenio Europeo de Derechos Humanos se planteó una reserva al art. 11 por posible contradicción con el art. 28 de nuestra Constitución. 
El control de la constitucionalidad material de los tratados se ha manifestado históricamente como un epígrafe del control de la constitucionalidad de las leyes. El Derecho comparado ofrece hoy un amplio abanico de soluciones, que van de la negativa estricta a considerar el control de la constitucionalidad de las leyes a su más amplia aceptación, con numerosas variantes por lo que se refiere al carácter del órgano u órganos llamados a efectuarlo (político o jurisdiccional, especial u ordinario, centralizado o descentralizado), al alcance de su intervención, al número y condición de los sujetos legitimados para suscitarla, a sus efectos. Dentro de este cuadro general cabe bosquejar el control de constitucionalidad de los tratados con los siguientes trazos: 1) allí donde se rechaza el control de constitucionalidad de las leyes se prescinde igualmente de verificar la de los tratados. Alguna Constitución, como la holandesa (art. 60, párrafo tercero), prohíbe expresamente su control, estableciendo así una presunción iuris et de iure de constitucionalidad; 2) los controles reparadores de la constitucionalidad de las leyes absorben frecuentemente a los tratados, ayunos de mención. Hans Kelsen era partidario de ello ${ }^{11}$, y en ese sentido se orientaron después de la Segunda Guerra Mundial los Tribunales Constitucionales de Italia y de la República Federal de Alemania. La equiparación del tratado a la ley, el ropaje legal con que se visten las autorizaciones parlamentarias de conclusión del tratado o la fortuna de concepciones dualistas acerca de las relaciones entre el Derecho internacional y el Derecho interno propician - no determinan - la extensión. Ocasionalmente se advierten en textos constitucionales disposiciones que - presupuesto el control - atienden a la particular condición de los tratados (Constitución austríaca, art. 140.a, añadido en 1964). Pero hay alguna Constitución (como la turca de 1961, art. 65, último párrafo) que, teniendo en cuenta dicha condición, opta por sustraerlos al control de la constitucionalidad que se cierne sobre las leyes, y 3) los controles preventivos de constitucionalidad suelen encontrar en los tratados uno de sus específicos supuestos (Constitución francesa, art. 54; portuguesa, art. 277.1). Experimentables antes de la prestación del consentimiento en el orden internacional, estos controles se ajustan a las exigencias propias de este orden. No es, pues, de extrañar que cuenten con una aceptación doctrinal mayor que la que se depara a los controles previos de constitucionalidad de las leyes, justo lo contrario de lo que ocurre con los controles reparadores, inconvenientes desde un punto de vista internacional.

2. Una de las novedades más significativas de la Constitución española de 1978 ha consistido en la amplia cobertura ofrecida al control de la constitucionalidad de las leyes, control que ha arrastrado al de los tratados atendiendo a una doble consideración: de una parte, era lógico que, aceptada la fiscalización para las leyes, se plantease su posibilidad y conveniencia respecto de los tratados; de otra, la forma o fuerza de ley de algunos de los actos domésticos relacionados con la formación y ejecución de los acuerdos internacionales y la común equiparación de las cláusulas convencionales a las disposiciones legales favorecían en un plano interno las actitudes favorables a la extensión. $\mathrm{La}$ confluencia de estos dos signos en la Constitución vigente ha

"H. Kelsen, La garantie jurisdictionnelle de la Constitution (La justice constitutionnelle), «R. D. P. et de la S. C.», 1928, págs. 231-233. 
provocado consecuencias espectaculares que chocan con la situación constitucional y fáctica previa. El único antecedente válido, dentro de sus limitaciones, que cabe encontrarle dentro de nuestro Derecho lo ofreció la Constitución de la II República (1931) al concebir, no sin recelos, un Tribunal de Garantías Constitucionales de disparatada composición y heterogéneas atribuciones, cuya vida fue breve, torpe y desdichada. Constituciones monárquicas del siglo xIx y leyes fundamentales del régimen del general Franco, práctica parlamentaria y jurisprudencia anterior y posterior, revelan que leyes y tratados no estuvieron, antes o después, sujetos a crisol alguno de constitucionalidad. Se careció de órganos específicos de control; se limitó la competencia de los jueces ordinarios.

Los diputados que aprobaron la primera de nuestras leyes fundamentales, la de 1812 , temieron, ciertamente, por su infracción; pero de haber osado alguien apuntar que ésta podía ser el resultado de su actividad legislativa, le habrían enviado los padrinos. Las Cortes eran el guardián de la Constitución. De no estar reunidas, su Diputación Permanente, vigilante, velaría por su observancia y tomaría nota de las infracciones cometidas. En sus primeras sesiones, la Cámara pondría remedio y haría efectiva la responsabilidad de los contraventores. Las Cortes eran, por otro lado, el oráculo de la Constitución a través de las leyes. Los jueces debían limitarse a aplicarlas, no pudiendo bajo ningún concepto suspender su ejecución ${ }^{12}$. Las Constituciones posteriores, que fueron entrando en vigor a lo largo del siglo xIX, más parcas de expresión, se ajustaron al mismo marco, que, por lo demás, era el prevalente en los países europeos. Se estimó, en consecuencia, que la norma fundamental contenía mandatos dirigidos exclusivamente a los legisladores, que sus preceptos serían aplicables por los jueces sólo en la medida en que se tradujeran en leyes y disposiciones generales cuya conformidad con aquéllos no era de su incumbencia examinar. La presunción de la constitucionalidad de las leyes devenía absoluta.

Ni la Constitución de 1931 ni la LOTGC de 1933 hicieron mención de los tratados al regular el control de la constitucionalidad encomendado a la alta jurisdicción a tal efecto creada. No faltaron, sin embargo, en el proceso constituyente y en su desarrollo legislativo alusiones, votos particulares y enmiendas, cuyo propósito era el de excluirlo o, por el contrario, incluirlo expresamente. Estas posiciones quedaron señaladas ya desde el primer momento. El anteproyecto de Constitución preparado y presentado por la Comisión Jurídica Asesora a la Cortes, tras implantar el control de constitucionalidad de las leyes, excluyó de manera explícita a «los tratados y convenios internacionales ratificados parlamentariamente» (art. 100.a). Uno de los vocales de la Comisión, J. Elola, que tan destacado papel iba a desempeñar en la articulación de la justicia constitucional en nuestro país, disconforme con la propuesta, trató de salvar en un voto particular el establecimiento de un control preventivo de la constitucionalidad de los tratados ${ }^{13}$. Ni uno ni otra sugerencia

12 Véanse los arts. 160, 246, 372 y 373 de la Constitución de 1812.

${ }^{13}$ Véase R. Reyes, La defensa constitucional, Madrid, 1934, págs. 52-54. Con carácter más amplio, el control de la constitucionalidad de los tratados habría sido sostenido en algunos de los trabajos doctrinales que en los últimos compases de la Dictadura de Primo de Rivera contemplaron la construcción de un nuevo orden constitucional. Así, por ejem 
tuvo fortuna. La exclusión formulada por el anteproyecto desapareció del proyecto elaborado por la Comisión de Constitución de las Cortes (18 de agosto de 1931), seguramente por innecesaria ante los muy serios recortes -hasta la desnaturalización- que sufrió el mismo control de la constitucionalidad de las leyes (art. 117). El voto de Elola no se incorporó, por otro lado, al proyecto. Su autor lo mantuvo en una enmienda a dicho artículo, de alcance más amplio, requiriendo que el Tribunal de Garantías tuviese competencia para estatuir definitivamente sobre «la constitucionalidad de los tratados y convenios internacionales, que examinará antes de su ratificación» ${ }^{14}$. A la postre, la Constitución guardó silencio sobre los tratados. No obstante, la cuestión volvió a florecer al debatirse el proyecto de ley orgánica del Tribunal de Garantías en 1933. Con formulaciones diferentes, el control de la constitucionalidad de los tratados fue sostenido por Recaséns Siches ${ }^{15}$ y por el ya mencionado Elola ${ }^{16}$. El primero perseguía establecer un control preventivo y además un control reparador limitado en el tiempo, pues lo extendía desde la fecha de la autenticación del texto del tratado («desde que fueren firmados») hasta un término ulterior a la prestación del consentimiento («el año siguiente de su ratificación»). Si se atiende a las explicaciones dadas por Recaséns ${ }^{17}$, se deduce que su propósito era limitar el control a la constitucionalidad extrínseca o formal, sin abarcar la material, pero este objetivo no llega a reflejarse en la redacción de la enmienda ${ }^{18}$. Por lo que se refiere a Elola, su enmienda, abandonando el terreno de los controles previos en que se había movido dos años antes, propone un control a posteriori amplísimo, sin límites temporales, aplicable tanto a la dimensión extrínseca de la constitucionalidad («tratados internacionales concertados con violación de las formalidades») como a la intrínseca o material («tratados internacionales concertados con violación de... principios consagrados por la Constitución»). Estas enmiendas fueron, finalmente, retiradas y la ley acabó disponiendo que podrían ser objeto del recurso de inconstitucionalidad las leyes, decretos legislativos y de urgencia de la República, así como las leyes y decretos emanados de las regiones autónomas (art. 28). Sería, en cualquier caso, apresurado concluir que con ello se cerraba el camino al control de la constitucionalidad de los tratados. EI mismo Recaséns justificó el abandono de su enmienda considerando que, de llegar a plantearse el problema, podría solventarse mediante una interpreta-

plo, V. Roig Ibáñez, La Constitución que España necesita, Madrid, 1929, cit. por R. Reyes, op. cit., pág. 158.

${ }_{14}$ Véase «D. de S.», 25 de noviembre de 1931, núm. 80, ap. $1 .^{\circ}$, y 26 de noviembre, número 81.

${ }^{15}$ Véase «D. de S.», 26 de mayo de 1933, núm. 345, ap. 1.

${ }^{16}$ Véase $\ll \mathrm{D}$. de $\mathrm{S} . », 30$ de mayo de 1933 , núm. 346 , ap. $10^{\circ} \mathrm{Tb}$. su voto particular a la totalidad del tít. III de la LOTGC (ibid., ap. $40^{\circ}$ ).

${ }^{17}$. Véase «D. de $\mathrm{S} . », 24$ y 31 de mayo de.1933, núms. 343 y 347.

${ }^{18}$ Lo mismo cabe decir del voto particular formulado al anteproyecto de la LOTGC entregado al Gobierno el 2 de agosto de 1932 por la Comisión Jurídica Asesora (véase R. Reyes, op. cit, pág. 177), suscrito, entre otros, por A. de Luna, en el que se pronunciaban por la mención expresa del recurso de inconstitucionalidad contra tratados internacionales con una motivación que inclina a creer que su pensamiento estaba en la inconstitucionalidad extrínseca de tratados concluidos sin la autorización requerida por la Constitución. 
ción extensiva ${ }^{19}$, criterio generalizado entre los comentaristas de la ley ${ }^{20}$ que no hubo ocasión de contrastar en la práctica.

La normativa en vigor ha implantado tanto controles preventivos como reparadores de la constitucionalidad de los tratados, gestionados por un órgano ad boc del máximo rango, un auténtico poder del Estado: el Tribunal Constitucional. La misma Constitución atribuye al Tribunal el control preventivo de la constitucionalidad intrínseca o material de los tratados (art. 95.2). Pero no es éste el único control de tal naturaleza. Aprovechando que el artículo 161.1.d de la norma fundamental ofrece un cauce para ampliar el ámbito competencial de este órgano, su propia ley reguladora ha articulado un control previo de las leyes orgánicas (art. 79) que puede tener trascendencia en relación con tratados de atribución a una organización internacional del ejercicio de competencias derivadas de la Constitución, cuya conclusión ha de ser autorizada mediante una ley de esta clase (art. 93). A primera vista, este control parece reservado a la dimensión extrínseca o formal de la particular categoría de tratados a la que atañe, y, ciertamente, es ahí donde su experimentación ha de resultar más provechosa. Es, con todo, posible sostener su aplicación a la dimensión intrinseca o material en la medida en que la impugnación de una ley orgánica de autorización gire en torno a la contrariedad de las estipulaciones del tratado con la Constitución, lo que haría inviable la vía del artículo 93 para su celebración. Podrá advertirse en este caso la superposición de los controles previstos en los artículos 95.2 de la Constitución y 79 de la LOTC. No obstante, la apertura en la lista de sujetos legitimados para experimentarlo permiten al último ofrecer oportunidades que niega el primero. Aportación también de la LOTC ha sido la mención expresa de los tratados entre los textos susceptibles de un control reparador (art. 27.2.c). La Constitución aludía únicamente a «las leyes y disposiciones normativas con fuerza de ley» (art. 161.1.a), precepto que, al igual que el apartado d) del mismo artículo, ha sido ordeñado por los redactores de la ley.

\section{III}

1. La implantación de un servicio de diagnóstico precoz de la (in)constitucionalidad intrinseca o material de los tratados, llamado a funcionar antes de que en el plano internacional se hubiere dado el casi irreversible paso de su perfeccionamiento, se decidió por los miembros de la ponencia constitucional en el mismo momento en que desestimaron la posibilidad de que por vía de tratado se gestasen excepciones a la Constitución. El mecanismo propuesto en el anteproyecto de 17 de abril de 1978 (art. 88), consistente en atribuir competencia al Tribunal Constitucional para, a requerimiento del Gobierno - de cualquiera de las Cámaras, declarar si existe o no contrariedad entre las estipulaciones del tratado y la Constitución, no fue objetado, ni siquiera deba-

19. Véase «D. de S.», 31 de mayo de 1933, núm. 347.

20 Véanse, por ejemplo, F. de Arcaya, El Tribunal de Garantías Constitucionales, Madrid, 1934, pág. 22; R. Reyes, op. cit., pág. 179; L. Legaz Lacambra, Las garantías constitucionales del Derecho internacional (con especial referencia a la Constitución española), «R. D. P.», 1933, págs. 310-311. 
tido, en las posteriores etapas del proceso constituyente. Sólo buscando una formulación más clara y ordenada, donde quedaran deslindados los aspectos sustantivo y procesal, se produjo el desdoblamiento del precepto en dos números. Fue una sugerencia del senador Sánchez Agesta, aceptada por la Comisión de Constitución de la Cámara Alta, la que lo originó ${ }^{21}$. De ahí el vigente artículo 95.2, hoy complementado por los preceptos de la LOTC (artículos 2.1.e, 10.d y 78).

Destaquemos los rasgos del mecanismo establecido. El primero a subrayar es el de la naturaleza del órgano competente. Al designar como tal al Tribunal Constitucional se ha optado por un control judicial especial; al conferir la competencia al Pleno (art. 10.d de la LOTC) se atiende a la importancia de la función atribuida.

Un segundo rasgo, de la mayor trascendencia, consiste en que el Tribunal no puede actuar de oficio, sino sólo a instancia de un corto y cerrado número de órganos (Gobierno y Cámaras legislativas), legitimados para requerir su intervención si lo estiman oportuno. El carácter facultativo de la solicitud, el desencadenamiento potestativo y no preceptivo del control, ha sido señalado como uno de sus defectos ${ }^{22}$. Pero más que eso es la estrechez con que ha sido concebida la legitimación activa ante el Tribunal la que puede asestar un golpe bajo en la bragadura del control ${ }^{23}$. La exclusión del jefe del Estado es lógica y nadie ha pretendido rectificarla. Todos los actos del rey, salvo el nombramiento y despido de los miembros civiles y militares de su Casa, están sujetos a refrendo (arts. 56.3, 64 y 65.2 de la Constitución), y en la celebración de los tratados su papel se sitúa en la escena de la formalización de una decisión de Gobierno y no en el de la adopción de la decisión. Tal vez su función arbitral pudo aconsejar el reconocimiento de una cierta legitimación para, en ese momento, plantear la cuestión de la constitucionalidad intrínseca del tratado, pero se ha preferido por todos que nada relacionado con la política concreta salpique su condición simbólica y representativa (art. 56.1). La legitimación del Gobierno es, ciertamente, inobjetable. Cabe dudar, sin embargo, de su disponibilidad para poner en marcha el mecanismo de control. El Gobierno es, en efecto, el hacedor del tratado y el depositario de la iniciativa para la evacuación del trámite parlamentario. Decidido políticamente a la conclusión, no parece ser el órgano tentado a inquirir el horóscopo de constitucionalidad de un convenio que le interesa perfeccionar. Sólo el desacuerdo entre los componentes de una coalición que diese vida al Gobierno, un cambio en su composición y orientación política o, tal vez, un incómodo dictamen

${ }^{21}$ Enm. núm. 343. Véase supra, nota 9.

${ }_{22}$ Véase J. Almagro Nosete, Justicia constitucional (Comentarios a la ley orgánica del Tribunal Constitucional), Madrid, 1980, pág. 348.

${ }_{23}$ En el proceso constituyente sólo la enm. núm. 62 (Progresistas y Socialistas Independientes) de las presentadas en el Senado sugirió -en relación con la núm. 93- una ampliación considerable del número y condición de los legitimados para requerir el control previo de constitucionalidad de los tratados. Además del Gobierno, hubieran gozado de este derecho la décima parte de los diputados, la décima parte de los senadores, los órganos colegiados ejecutivos de las Comunidades Autónomas, la tercera parte de los miembros de sus Asambleas y el Defensor del Pueblo. Pero la enmienda fue retirada por el portavoz del grupo enmendante en la Comisión (Villar Arregui) sin que se sometiera a voto (6 de septiembre de 1978, «D. de S.», núm. 50). 
del Consejo de Estado, con el que, en todo caso, ha de contar ${ }^{24}$, permitirían corregir el sentido de la presunción. ¿Será acaso mayor la disponibilidad de las Cámaras legislativas - Congreso de los Diputados y Senado- para solicitar del Tribunal el control previo de constitucionalidad? Al referirse el artículo 95.2 a las Cámaras, a cualquiera de las Cámaras, sin más precisiones, ha de entenderse que su requerimiento sólo es factible en las condiciones de quorum y mayoría previstas con carácter general para la formación de su voluntad orgánica ${ }^{25}$, mayoría que será, con toda probabilidad, una mayoría gubernamental. Las minorías discrepantes son, por consiguiente, desatendidas cuando antes de la conclusión del tratado denuncian, frente a la mayoría parlamentaria, su inconstitucionalidad. ¿No hubiera sido oportuno reconocerles el derecho de acceder a un órgano inicialmente independiente llamado a resolver con criterio y método jurídico - si es que ello fuere posible- y no político la cuestión? Se ha aducido, en apoyo de una contestación negativa, que el requerimiento podría ser adulterado, utilizado como instrumento dilatorio, retardatario de la estipulación de un tratado por quienes políticamente lo combaten; que es altamente inconveniente trasladar al Tribunal el conflicto político existente en el seno de las Cámaras; que su declaración, aunque fuese el resultado de un riguroso discurso jurídico, sería leída y analizada con talante político, perjudicando su autoridad. Pero esta argumentación, favorable a una aproximación institucional a la legitimación, no me parece convincente: $1 .^{\circ}$ ) porque todos los males que anuncia tienen remedio ponderando adecuadamente el número o porcentaje de parlamentarios que se ha de alcanzar para despachar la solicitud, agilizando el procedimiento y reclamando templanza a los grupos parlamentarios; $2 .^{\circ}$ ) porque el objetivo primordial del control es la salvaguarda de la Constitución y, en relación con las Cámaras legislativas, son las mayorías y no las minorías las que determinan los actos que pueden violentarla, y $3 .^{\circ}$ ) porque los peligros del acceso de las minorías al Tribunal son independientes del carácter preventivo o reparador del control, siendo un despropósito negarlo en el primer supuesto y aceptarlo en el segundo - como, desde luego, ocurre

${ }^{24}$ Según el art. 22.1 de la ley orgánica del Consejo de Estado, «la Comisión Permanente del Consejo de Estado deberá ser consultada... en todos los tratados o convenios internacionales sobre la necesidad de autorización de las Cortes Generales con carácter previo a la prestación del consentimiento del Estado». Véase mi trabajo La autorización parlamentaria de la conclusión de los tratados internacionales: el problema de la calificación, «R. Esp. D. I.», 1980, págs. 123-142. Según A. J. Rodríguez Cartión (Control de los tratados internacionales en el sistema parlamentario español, 1981 -mimeo-, pág. 124), la redacción literal de esta disposición no consiente al Consejo de Estado manifestarse sobre la compatibilidad de las cláusulas convencionales con la Constitución. Esta opinión es demasiado rigurosa. Por una parte, si el órgano consultivo ha de dictaminar sobre la necesidad de autorización, es inevitable que para formar su juicio aprecie la constitucionalidad del tratado. Por otra parte, la propia razón de ser de la intervención del Consejo y las competencias generales que se le reconocen - que le hacen no sólo velar por «la observancia de la Constitución y del resto del ordenamiento jurídico», sino también valorar «los aspectos de oportunidad y conveniencia», lo solicite expresamente o no el Gobierno (art. 2.1) - reclaman una interpretación amplia. Por último, el art. 22.1 de la ley establece un mínimo preceptivo, no un máximo limitativo de la intervención del Consejo. Véase el dictamen del Consejo de Estado de 27 de agosto de 1981, referente a las condiciones de adhesión de España al Tratado del Atlántico Norte.

${ }_{25}$ Así lo presume O. Alzaga, La Constitución española de 1978 (comentario sistemático), Madrid, 1978, pág. 597. 
en nuestro país, donde la misma Constitución es bien explícita en reconocer a cincuenta diputados o a cincuenta senadores la facultad de interponer recursos de inconstitucionalidad contra leyes vigentes y disposiciones normativas con fuerza de ley (arts. 161.1.a y 162.1.a) - a menos que se haya caído en el maquiavélico cálculo de que el Tribunal siempre será más reacio a declarar la inconstitucionalidad de un tratado en vigor que de un tratado aún no perfeccionado. La genérica referencia a las Cámaras del artículo 95.2 de la Constitución pudo avivar la esperanza de que el desarrollo legislativo del precepto pudiera servir para socorrer estas deficiencias: ad ex, disponiendo el deber de los respectivos presidentes de plantear el requerimiento a petición de un número determinado de diputados o de senadores o de uno o varios grupos parlamentarios. Pero la LOTC (art. 78.1) se ha limitado a repetir en este punto los términos de la Constitución ${ }^{26}$. Así que, teniendo en cuenta de que bajo ciertas condiciones las minorías parlamentarias están legitimadas para interponer a posteriori, en los tres meses siguientes a su publicación, recurso de inconstitucionalidad contra los tratados, roguemos por el buen sentido de los órganos legitimados para experimentar el control previo cuando, de no hacerlo, se perfile amenazadora la insidiosa sombra de ese recurso ${ }^{27}$. Pero no sólo las minorías ideológicas han sido marginadas; también lo han sido las minorías territoriales, los órganos de las Comunidades Autónomas, sus representantes. De admitir - hay quien lo discute - la legitimación de asambleas y ejecutivos autonómicos para interponer recurso de inconstitucionalidad contra tratados internacionales ya perfeccionados que afecten a su propio ámbito de autonomía, se reproduciría la desarmonía lógica y práctica que acabo de señalar. La inclusión, por otra parte, entre los textos protegidos por el control

${ }^{26}$ El Reglamento del Congreso de los Diputados (1982) añade rigores suplementarios al disponer (art. 157.1) que «si durante la tramitación de un tratado o convenio... se súscitaren dudas acerca de la constitucionalidad de alguna de sus estipulaciones, el Pleno del Congreso, a iniciativa de dos grupos parlamentarios o una quinta parte de los diputados, podrá acordar dirigir al Tribunal Constitucional el requerimiento previsto en el art. 95.2 de la Constitución». No ya la decisión de solicitar el dictamen, sino la simple propuesta de decidir la solicitud, se somete a un régimen severo. El texto elaborado por la ponencia aún lo era más, al otorgar la iniciativa al presidente de la Cámara $y$ tres grupos parlamentarios o una quinta parte de los diputados. Una enmienda, la núm. 215 (G. P. Comunista), sugirió conceder la iniciativa, alternativamente, al presidente, dos grupos parlamentarios o una décima parte de los diputados, eliminando toda tentación interpretativa de veto presidencial y reduciendo el techo de la legitimación de grupos parlamentarios y diputados, pero la ponencia sólo estuvo dispuesta a aceptar la enmienda en relación con el número de grupos parlamentarios necesarios. En el debate en Comisión, sin embargo, y como resultado final de una enmienda in voce de Del Valle y Pérez, se eliminó, con la oposición del portavoz —entonces- de UCD, Herrero de Miñón, la alusión al presidente dé la Cámara.

${ }^{27}$ El debate parlamentario sobre la autorización solicitada por el Gobierno para adheritse al Tratado del Atlántico Norte ha ofrecido una primera oportunidad para comprobar las limitaciones del sistema. Descontando el hecho de que las proposiciones no de ley para que las Cámaras requiriesen el pronunciamiento del Tribunal Constitucional sobre la existencia o no de contradicción entre determinados arts. de la Constitución y del tratado se han desplazado a aspectos de constitucionalidad extrínseca o formal, manifiestamente ajenos al control previsto por el art. 95.2 de la Constitución, la negativa de la mayoría a endosar las proposiciones ha conducido a los proponentes a anunciar su intención de tecurrir a posteriori al Tribunal con base en el art. 161.1.a de la Constitución. Véase infra, IV.1 y 2. 
de constitucionalidad, de las leyes dictadas para delimitar las competencias del Estado y de las diferentes Comunidades Autónomas o para regular o armonizar el ejercicio de las atribuciones de éstas no es un argumento precisamente a favor de la preterición de tales órganos.

El tercer tasgo corresponde a los límites temporales dentro de los cuales ha de experimentarse el control. Estamos ante un control a priori, preventivo - y, como tal, necesariamente abstracto-, que ha de realizarse entre la fecha de autenticación del texto del tratado (límite inicial) y la de su perfeccionamiento en el orden internacional (límite final). Implícitos en el artículo 95.2 de la Constitución, estos límites han sido formulados inequívocamente por el artículo 78.1 de la LOTC al disponer que los requerimientos de los órganos legitimados se referirán a tratados «cuyo texto estuviera ya definitivamente fijado, pero al que no se hubiere prestado aún el consentimiento del Estado». El límite inicial fijado hace improcedente la consulta sobre textos hipotéticos o provisionales barajados en el curso de una negociación todavía abierta. Ahora bien: una vez que dispone de un texto definitivo, el Gobierno puede requerir la declaración del Tribunal antes de solicitar de las Cortes la autorización para la conclusión del tratado, y cabe imaginar que es lo que hará cuando su iniciativa no sea inducida por la presión política proveniente de las Cámaras. Nada le impide, en cualquier caso, ejercitar su facultad durante o después de la tramitación parlamentaria del tratado. Por lo que se refiere al Congreso de los Diputados y al Senado, aunque su requerimiento puede verificarse en cualquier momento dentro de los límites temporales establecidos, será el pase por la Cámara de la solicitud gubernamental de autorización de la conclusión del tratado la chispa que normalmente encenderá la ocasión de plantearlo ${ }^{23}$. Será razonable que las proposiciones que se hagan en este sentido sean debatidas con carácter preliminar, no entrando en la petición de autorización sino después de que hayan sido puestas a votación y desestimadas ${ }^{29}$. Aprobado, en cambio, el planteamiento del requerimiento al Tribunal Constitucional, debe entenderse que se interrumpe el iter formativo de la voluntad del Estado ${ }^{30}$. La LOTC no lo ha dispuesto expresamente y, atendiendo a ello, cabría también sostener que el efecto suspensivo sólo ha de afectar a la última de sus etapas, la manifestación del consentimiento, que es el mínimo exigido por la naturaleza del control solicitado y el carácter de la declaración del Tribunal ${ }^{31}$.

${ }^{28}$ El Reglamento del Congreso de los Diputados (1982; art. 157.1) -véase nota 26parte de esta hipótesis exclusivamente al regular el ejercicio por la Cámata del derecho que le reconoce la Constitución y la LOTC.

${ }_{29}$ Así se hizo en la primera ocasión en que tales proposiciones se han formulado, al solicitarse la autorización para la adhesión de España al Tratado del Atlántico Norte. No obstante, el debate no se ha ceñido, como hubiera sido de desear, a los pros y a los contras del requerimiento de control, sino que quienes lo solicitaban lo utilizaron para combatir por anticipado, en términos políticos, la autorización requerida. Ello es técnicamente incorrecto y crea tensiones innecesarias, pero es explicable - y rentable - políticamente, cuando se presume que la proposición que se hace va a ser derrotada.

${ }^{30}$ Véase en este sentido J. González Pérez, Derecbo procesal constitucional, Madrid, 1980, pág. 272; E. García de Enterría, Curso de Derecbo administrativo, I, Madrid, 1980 , página 160 .

${ }^{31} \mathrm{Al}$ debatirse en el Congreso de los Diputados la adhesión de España al Tratado del Atlántico Norte, el portavoz socialista, G. Peces-Barba, exteriorizó las dudas existentes al respecto ( $\ll D$. de S.», 27 de octubre de 1981). 
No obstante, no veo las razones para aceptar este punto de vista minimalista. ¿Para qué forzar una decisión de las Cámaras? Si éstas resuelven no autorizar la conclusión, ¿no está de más la declaración del Tribunal? Si, por el contrario, otorgan la autorización, ¿en qué lugar quedarán de ser declarada la inconstitucionalidad del tratado? ${ }^{32}$.

La ley ha previsto un procedimiento ágil, rápido $\mathrm{y}$, parece, escrito que debe retrasar lo menos posible el natural proceso de gestación de la voluntad del Estado en obligarse por un tratado internacional. En él podrán intervenir todos los órganos legitimados y, eventualmente, si así lo estima el Tribunal, otras personas físicas o jurídicas, órganos del Estado y de las Comunidades Autónomas. Recibido el requerimiento, dice el artículo 78.2, primer inciso, de la LOTC, el Tribunal Constitucional emplazará al solicitante y a los restantes órganos legitimados ${ }^{33}$, esto es, al Gobierno y a ambas Cámaras, a fin de que en el término de un mes expresen su opinión fundada sobre la cuestión. En cualquier momento (art. 78.3) podrá el Tribunal solicitar de tales órganos o de otros del Estado y de las Comunidades Autónomas, personas físicas y jurídicas, cuantas aclaraciones, ampliaciones o precisiones estime necesarias, dando para ello un plazo máximo adicional de treinta días. Dentro del mes siguiente al transcurso de ese plazo emitirá su decisión (art. 78.2, segundo inciso). La letra de la ley parece establecer el informe preceptivo del Gobierno y de las Cámaras acerca de la constitucionalidad del tratado. Estimo, sin embargo, que los órganos legitimados para interponer el requerimiento tienen el derecho, más que el deber, a personarse y ser oídos ${ }^{34}$. Por otro lado, la regulación del procedimiento no impide la comunicación de las respectivas opiniones a los demás legitimados, con la consiguiente posibilidad de respuesta en la medida en que el Tribunal abra el plazo complementario que le permite la ley.

La decisión del Tribunal es vinculante. «El Tribunal Constitucional - dispone el último inciso del núm. 2 del art. 78 de la LOTC- emitirá su declaración, que, de acuerdo con lo establecido en el artículo 95 de la Constitución, tendrá carácter vinculante.» $\mathrm{La}$ verdad es que el precepto constitucional no dice tanto. Realmente no dice nada acerca de la vinculatoriedad de la declaración, impuesta por la lógica, la naturaleza y razón de ser del control que se establece y no por su letra. Por tanto, si la declaración afirma la no contrariedad del tratado con la Constitución, la tramitación de aquél podrá seguir adelante, centrada ya en las apreciaciones de oportunidad que aconsejan o desaconsejan políticamente autorizar su conclusión. En caso contrario, se renegocian o se reservan, si ello es posible, las estipulaciones convencionales que, según el

${ }^{32}$ De ahí que sea muy oportuna la regulación del Reglamento del Congreso de los Diputados (1982; art. 157.2) al establecer que, una vez requerido el Tribunal, «la tramitación del tratado o convenio se interrumpirá», reanudándose sólo en el caso de que el criterio de aquél sea favorable a la constitucionalidad de las estipulaciones convencionales.

${ }_{33}$ Según J. González Pérez, op. cit., págs. 272-273, el Tribunal Constitucional emplazará y recabará la opinión de los órganos legitimados que no hubiesen instado el dictamen. El emplazamiento y la recepción de informes del solicitante son, sin embargo, expresamente establecidos en el art. 78.2 de la LOTC.

${ }^{34}$ Los Reglamentos de las Cámaras no prevén cómo habrán de elaborarse tales informes. Por otra parte, el incumplimiento de los plazos puede plantear problemas cuando no estén en sesión. 
Tribunal, son incompatibles con los preceptos constitucionales, o se revisa la Constitución antes de consentir el tratado, o se renuncia al tratado. De hecho se establece, como se ha dicho, «una especie de veto judicial por inconstitucionalidad» ${ }^{35}$.

La naturaleza de la decisión ha sido discutida. Para unos, es una verdadera sentencia ${ }^{36}$. Para otros, se trata de un dictamen, porque, dicen, la actuación del Tribunal no es propiamente jurisdiccional, sino consultiva ${ }^{37}$. La ley, por su parte, se limita a denominarla declaración en la cabecera del capítulo primero del título VI y en el número 2 del artículo 78, sustantivando el verbo empleado en el artículo 95.2 de la Constitución. El proyecto hablaba de juicio, término eliminado por la ponencia al advertir, gracias a una enmienda del Grupo Socialista, su incorrección técnica ${ }^{38}$. La cuestión puede tener relevancia en la medida en que del hilo de la terminología saquemos el ovillo de los efectos jurídicos procesales de la decisión. Declarada la compatibilidad del tratado con la Constitución, ¿podrá ser invocada como fundamento de una excepción de cosa juzgada en el caso de que posteriormente se plantee un recurso o una cuestión de constitucionalidad en relación con el mismo tratado? La contestación es controvertida. La decisión, se dice para sustentar el no, no es una sentencia; nada en la Constitución o en la ley impide la ulterior impugnación del tratado ${ }^{39}$; el artículo 79.5 de la LOTC, al regular los efectos del pronunciamiento del Tribunal en el otro supuesto de control previo -el de las leyes orgánicas-, dispone que no prejuzga su decisión en los recursos que pudieren interponerse tras la entrada en vigor del texto impugnado, criterio extensible al caso que nos ocupa. Pero este argumento puede retorcerse: el silencio del artículo 78 en punto que el artículo 79 afronta equivale a la afirmación del principio contrario; el tratado no es la ley; el propio artículo 79.5 admite otras interpretaciones y no basta con razonar en términos de «proceso» y «sentencia» para negar a la declaración prevista en el artículo 78 de la LOTC todo efecto ulterior ${ }^{40}$. La controversia sigue viva; y no es suficiente para deshincharla señalar que en cualquier caso el Tribunal, por coherencia, no adoptará resoluciones contradictorias. De un día para otro, las circunstancias -y la composición- del Tribunal pueden cambiar...

¿Cuáles son los textos sometidos al control previo de constitucionalidad previsto en el artículo 95 de la Constitución? Obviamente, los tratados inter-

${ }^{35}$ L. Sánchez Agesta, Sistema político de la Constitución española de 1978, Madrid, 1980, pág. 385.

${ }^{36}$ E. García de Enterría, op. cit., pág. 160.

${ }_{37} \mathrm{~J}$. González Pérez, op. cit., págs. 270 y 273 . El término dictamen fue también utilizado en una enmienda in voce del grupo senatorial de UCD ( $\mathrm{DD}$. de S.», 14 de septiembre de 1978, núm. 55). «Negocio de jurisdicción roluntaria» lo considera J. Almagro, op. cit., pág. 348. Véase de este mismo autor El Derecho procesal en la nueva Constitucion, «R. D. P. I.», 1978, pág. 896. Tb. O. Alzaga, op. cit., pág. 597.

${ }^{38}$ Enm. núm. 54. La enmienda del Grupo Socialista sugirió el empleo de la voz dictamen, término apoyado en el proceso constituyente por el grupo senatorial de la UCD - véase nota anterior- y que tampoco tuvo en cuenta la ponencia.

${ }_{39}$ F. Rubio y M. Aragón, La jurisdicción constitucional, en La Constitución española de 1978 , estudio sistemático dirigido por los profesores A. Predieri y E. García de Enterría, pág. 825 .

${ }^{40} \mathrm{~J}$. Arozamena, El recurso de inconstitucionalidad, en El Tribunal Constitucional, Dirección General de lo Contencioso del Estado, vol. I, Madrid, 1981, págs. 149-150. 
nacionales posteriores a la fecha en que el Tribunal se ha formado y ha comenzado a ejercer sus competencias. Pero todos ellos, sea cual sea la denominación que se utilice como cabecera (tratado eo nomine, convenio, acuerdo, protocolo...), la forma de manifestación del consentimiento (ratificación, adhesión, aceptación, aprobación...) o cualesquiera otras variables en las que pueda pensarse. El discurso acerca de si el control afecta sólo a los tratados cuya conclusión reclama la autorización parlamentaria o también a todos los demás es estéril e innecesario, por cuanto la decisión sobre el fondo - constitucionalidad o no del tratado- prejuzgaría siempre la admisibilidad del requerimiento: los tratados que suponen modificación o derogación de alguna ley requieren para su estipulación la autorización de las Cortes (art. 94.1.e de la Constitución), y es evidente que un tratado cuyas cláusulas contrarían los preceptos constitucionales afecta a la ley, a la más elevada de ellas. Así, pues, para resolver sobre la admisibilidad habría que entrar en el fondo. La Constitución, por otra parte, y lo mismo cabe decir de la LOTC, se pronuncia con generalidad y su objetivo es muy claro: perseguir las estipulaciones convencionales contrarias a la Constitución allí donde se encuentren. La distinción entre tratados sometidos a la autorización parlamentaria y tratados que no lo están puede interesar en otro plano: a las Cámaras no les será fácil requerir el control del Tribunal en momento oportuno, a menos que el Gobierno les haya remitido el texto del tratado con objeto de obtener la autorización para la prestación del consentimiento. De cara al futuro cabe, por lo demás, plantearse si acaso este control previo de constitucionalidad no debería extenderse a otras obligaciones internacionales asumidas o asumibles por el Estado por vía no convencional $\longrightarrow$ por lo menos no directamente convencional-cuando tales obligaciones no estén llamadas a desarrollar efectos inmediatos en el orden interno como consecuencia de compromisos previamente concertados.

2. El único control previo de constitucionalidad previsto por la Constitución es el concerniente a los tratados internacionales. Pero la LOTC se ha servido - ha usado, según unos, y abusado, según otros- del artículo 161.1.d de la ley fundamental, que consiente extender la competencia del Tribunal a «las demás materias que le atribuyan... las leyes orgánicas», para ampliar ese control preventivo a los proyectos de estatuto de autonomía y de leyes orgánicas. ¿Qué mejor ley que la del propio Tribunal para cumplir esa misión?, parece que se preguntaron el Gobierno y los grupos parlamentarios dispuestos a apoyarlo. Cualquiera menos ella, replicaron los representantes de la izquierda y nacionalistas: el artículo 161.1. $d$ fue concebido con la mente puesta en leyes orgánicas sustantivas, no adjetivas, no la adjetiva del Tribunal, que, según dispone el artículo 165 de la Constitución, regulará su funcionamiento, el estatuto de sus miembros, el procedimiento y las condiciones para el ejercicio de las acciones. Un bello enredo. Llovieron las enmiendas de supresión de una manifestación de control preventivo en la que se sospechaban segundas intenciones políticas ${ }^{41}$. Se denunció la inconstitucionalidad de la ley rectora del órgano llamado a ser el guardián, el intérprete supremo de la Constitución.

${ }^{41}$ En el Congreso de los Diputados, enms. núms. 55 (G. Socialista), 83 (G. Socialistas de Cataluña), 181 (Minoría Catalana), 216 (Herrero de Miñón), 217 (G. Socialista Vasco), 222 (G. Vasco) y 288 (G. Comunista). En el Senado, enms. núms. 6 (R. Cercós) y 99 (Cataluña, Democracia y Socialismo). 
Por un momento los debates se elevaron sobre la habitual atonía ${ }^{42}$. Pero el Gobierno sacó adelante su punto de vista, y ahora sólo procede apuntar que el fallo no ha estado tanto en el vilipendiado artículo 79 de la LOTC, sino en el 161.1.d de la Constitución, que le ha servido de - discutible o nocobertura. Tenían razón quienes, ya antes de que el proyecto de LOTC saliera a la luz pública, objetaron esta norma en blanco, esta desconstitucionalización en bloque de las materias sujetas a la justicia constitucional, necesitadas de rigor formal: la Constitución, exclusivamente la Constitución, debía haber señalado expresamente todas las competencias del Tribunal, máxime cuando no había motivos técnicos que lo imposibilitaran ${ }^{43}$.

Al margen de su poco diáfana acta de nacimiento y de las contraindicaciones que este control pueda manifestar en otras áreas, hay que reconocer que, desde una perspectiva internacional(ista), los mecanismos profilácticos de constitucionalidad siempre son bien venidos. Considerado con este talante, el artículo 79 de la LOTC descubre al internacionalista la posibilidad de ensanchar el control previo de constitucionalidad de una categoría de tratados - la definida en el art. 93 de la Constitución- cuya celebración requiere, como se sabe, autorización parlamentaria mediante ley orgánica. La letra del precepto lo permite. Su propósito lo aconseja. La alegación - no pacíficade que en estos casos la ley es una simple forma, una cáscara del acto de autorización, no ha de impedirlo.

El recurso tendrá por objeto la impugnación del texto definitivo del proyecto de ley orgánica de autorización de la celebración de un tratado por el que se atribuya a una organización internacional el ejercicio de competencias derivadas de la Constitución, una vez tramitado en ambas Cámaras y después de que, en su caso, el Congreso se haya pronunciado sobre las enmiendas propuestas por el Senado. El recurso se podrá interponer en los tres días siguientes por el presidente del Gobierno, el Defensor del Pueblo, cincuenta diputados, cincuenta senadores, los órganos colegiados ejecutivos y las Asambleas de las Comunidades Autónomas (art. 32 de la LOTC en relación con el 79.2), y como consecuencia de la interposición se suspenderá automáticamente la tramitación del proyecto. El recurso se sustanciará como los de inconstitucionalidad de posible planteamiento a posteriori. Una declaración de inconstitucionalidad impedirá al proyecto seguir su curso en tanto no haya subsanado sus tachas; una declaración de conformidad con la Constitución permitirá proseguir la tramitación, pero el pronunciamiento del Tribunal no bloqueará

${ }^{42}$ Véase «D. de S. del Congreso», Pleno (23 de julio de 1979, núm. 23); Senado, Pleno (3 de septiembre, núm. 13).

${ }^{43}$ M. Aragón, El control de constitucionalidad en la Constitución española de 1978, «R. E. P.», 1979, núm. 9 (nueva época), págs. 178-179. Antes, N. Pérez-Serrano Jáuregui, La justicia constitucional y el Tribunal Constitucional, conf. inédita, Madrid, febrero 1978. R. de Vega, en Constitución española, ed. comentada, auspiciada por el C.E. C., Madrid, 1979, pág. 347, considera esta desconstitucionalización jurídicamente inadmisible y políticamente peligrosa. Para O. Alzaga, op. cit., pág. 932, en cambio, esta «percha legal», aun admitiendo su incorrección técnica, era útil y no había que exagerar sus riesgos. El peligro estaría en que se hubiera permitido por ley orgánica reducir, no aumentar, las competencias del Tribunal Constitucional. Sobre la inconstitucionalidad del art. 79 véase $t b$. $G$. Peces-Barba, El Tribunal Constitucional, en El Tribunal Constitucional, cit., vol. III, páginas 2053-2056. 
la ulterior experimentación de los controles reparadores ni prejuzgará su resultado.

La ampliación de la legitimación activa — junto con una cierta apertura al control de la constitucionalidád extrínseca- es la principal virtud de este recurso, aplicable a una determinada especie de tratados, frente al requerimiento concebido con alcance más general desde un punto de vista objetivo por el artículo 95 de la Constitución. Y es esa virtud precisamente la que empuja a poner énfasis en una vía de control que en otro caso resultaría redundante ${ }^{44}$. Las minorías, las Comunidades Autónomas, marginadas del control previo de los tratados dispuesto por el mencionado artículo 95 , podrán impugnar aquellos por los que se transfiera el ejercicio de competencias a organizaciones internacionales, antes de que se haya prestado el consentimiento del Estado, cuando consideren que la transferencia rebasa los límites dentro de los que la Constitución la autoriza. Por la peana - la ley orgánica de autorizaciónllegarán al santo -el tratado cuya inconstitucionalidad alegan-. La ley de autorización sería, en efecto, inconstitucional si lo fuera, por ser contrario a la norma fundamental, el tratado al que se refiere. Si a ello se añade que el denominado bloque de constitucionalidad, que ha de ser protegido por el Tribunal, incluye a los Estatutos de Autonomía y a las leyes de armonización del ejercicio de las competencias de las Comunidades Autónomas (art. 28.1 de la LOTC), estaremos en condiciones de calibrar la trascendencia y utilidad del mecanismo de control preventivo establecido. A este respecto ha de recordarse que el proyecto del Estatuto del País Vasco contenía una disposición según la cual ningún tratado podría afectar atribuciones y competencias de esta Comunidad a menos que se siguiera el procedimiento de reforma del Estatuto y se aprobara mediante referéndum de los electores censados en su territorio (art. 20.3, último inciso), disposición que no fue combatida de frente en la negociación posterior, pero que intentó ser desactivada por el Gobierno forzando un añadido final por el que se deja a salvo lo previsto en el artículo 93 de la Constitución (art. 20.3, último inciso, del Estatuto). Es improbable que los presuntos culpables de semejante texto, cuya constitucionalidad es dudosa, hayan tenido conciencia de su alcance. Consultadas las profecías de Nostradamus, advierto, por otra parte, que no se pronuncian al respecto. Es bueno, por tanto, que para atajar los numerosos problemas interpretativos que la historia ha de depararle, por la ambigüedad de su redacción y las variadísimas políticas a cuyo servicio puede entrar, el supremo intérprete pueda ser recurrido por los órganos representativos de los intereses en conflicto antes de que se perfeccionen en el orden internacional obligaciones de Estado.

El recurso no alcanza, por desgracia, a las demás especies de tratados. Estos, de necesitar para su conclusión la autorización parlamentaria, la obtienen mediante un acto singular sobre el que no es posible ejercitar un control preventivo, absolutamente inadvertido por la Constitución y por la LOTC. $\mathrm{Si}$ en términos generales el modelo adoptado por nuestros legisladores para

44 Lo hubiera sido, en efecto, de haber adoptado los criterios de legitimación activa propuestos en el proyecto de ley que, tal y como para la declaración de inconstitucionalidad previa de los tratados, la limitaba al Gobierno o a cualquiera de las Cámatas. Fue una enmienda (núm. 95) del senador A. Soriano B. de Lugo la que dio lugar a una ampliación de la legitimación. 
esta clase de control ha sido el francés, ¿por qué no se ha seguido en este punto? En Francia, las minorías parlamentarias carecen, como en España, de legitimación para plantear ante el Consejo Constitucional la conformidad o no de un compromiso internacional con la norma fundamental, pero a partir de la Ley Constitucional de 29 de octubre de 1974 un número de sesenta diputados o sesenta senadores está facultado para someter al Consejo la constitucionalidad de cualquier ley votada por el Parlamento - $\mathrm{y}$, por consiguiente, las de autorización o aprobación de compromisos internacionales - antes de su promulgación (art. 61 de la Constitución) ${ }^{45}$. A la postre, la diferencia se encamina a una reducción del período de interposición del requerimiento, pues los sesenta han de esperar a que se consume la tramitación parlamentaria, la conclusión del tratado quede autorizada y sólo reste la promulgación de la ley por el presidente de la República. Esta limitación temporal parece tan poco justificada que no faltan en los medios doctrinales quienes, saltando de artículo, reclaman la equiparación de las minorías con el jefe del Estado, el primer ministro y los presidentes de las Cámaras, legitimados conforme al artículo 54 de la Constitución para llevar la cuestión de constitucionalidad ante el Consejo desde el día de la autenticación del tratado. Se ganaría tiempo, se centraría la discusión posterior, se excusaría un debate innecesario ${ }^{46}$. Pero nosotros, ahora, bien que nos conformaríamos con asegurar el derecho de las minorías a someter al Tribunal la constitucionalidad de cualesquiera actos de autorización de la conclusión de tratados internacionales, cebo para el control de los mismos tratados, una traducción española en clave internacional del artículo 61 de la Constitución francesa.

${ }^{45} \mathrm{Ya}$ lo propuso el Comité consultivo constitucional, sin éxito, al redactar el proyecto de Constitución de 1958. La ley constitucional de 29 de octubre de 1974 ha sido un paliativo, si bien la enmienda por la que se admitía que una minoría de parlamentarios recurriera al Consejo Constitucional encontró fuerte oposición antes de lograr su aprobación. Véase, sobre la ley, P. Juillard, Difficultés du changement en matière constitutionnelle: l'aménagement de l'art. 61 de la Constitution, «R. D. P.», 1974, págs. 1073 y sigs.; C. Franck, Le nouveau régime des saisines du Conseil Constitutionnelle (loi constitutionnelle de 29 octobre 1974), «J. C. P.», 75.I, pág. 2678; L. Philip, L'élargissement de la saisine du Conseil Constitutionnel, «A. J. D. A.», 1975, pág. 15. En el pasado se ha discutido si las leyes de autorización de la conclusión de tratados -actos que de la ley tienen sólo el nombre- eran abarcadas por el control preventivo del art. 61 de la Constitución (véase, por ejemplo, a favor A. Cocatre-Zilgien, La Constitution de 1958, le Droit international, les relations extérieures et la politique étrangère, «Ann. Fr. D. I.», 1958, pág. 650; en contra, Ch. Rousseau, La Constitution de 1958 et les traités internationaux, Hommage Basdevant, Patís, 1960, pág. 469). Pero a partir de la decisión del Consejo Constitucional de 30 de diciembre de 1976 ya no caben dudas al respecto. La ampliación de la legitimación a las minorías parlamentarias hizo, por otro lado, que despertara el control de la constitucionalidad de los tratados. Si entre 1959 y 1975 sólo una vez -en 1970se sometió un tratado a control (decisión del 19 de junio de 1970), en 1975 el supuesto se dio en tres ocasiones (decisiones de 15 de enero y 30 de diciembre - dos-) y, posteriormente, en 1976 (30 de dicimbre), 1977 (20 de julio y 30 de diciembre-dos-), 1978 (18 de enero).

${ }^{46}$ Véanse N. Quoc Dinh, Le Conseil Constitutionnel français et les règles du Droit public international, «R. Gen. D. I. P.», 1976, págs. 1001 y sigs.; L. Favoreu, Le Conseil Constitutionnel et le Droit international, «Ann. Fr. D. I.», 1977, págs. 95 y sigs.; L. Saidj, Le Parlement et les traités. La loi relative à la ratification ou à l'approbation des engagements internationaux, París, 1979, págs. 77 y sigs.; F. Luchaire, op. cit.. págs. 391 y sigs.; Cl. Blumann, op. cit., págs. 537 y sigs., este último particularmente crítico (págs. 552-553). 
Otra característica del modelo francés - y para un internacionalista otra de sus ventajas - es la de que el control de constitucionalidad antecede siempre a la asunción de los compromisos internacionales. Concluido el tratado no podrá ser puesta en entredicho a posteriori su conformidad con la Constitución ${ }^{47}$. En España, en cambio, se acepta liberalmente la sujeción al control de los tratados obligatorios y vigentes, incluso en el supuesto de que con anterioridad a su estipulación definitiva el Tribunal hubiera declarado la constitucionalidad de sus cláusulas. La LOTC, en el cruce de caminos en que finalmente se detuvo la Constitución, ha tomado decididamente esta senda.

\section{IV}

1. En el proceso constituyente, la primera posición favorable a la apli cación a los tratados internacionales de los controles reparadores de constitucionalidad se identifica en un enmienda de adición formulada por UCD al anteproyecto de Constitución de 5 de enero de 1978, que había pasado por alto la cuestión ${ }^{48}$. La Ponencia, solícita, se hizo eco de ella y en el anteproyecto del 17 de abril se dispuso (art. 154.1.a) que el Tribunal sería competente para conocer «del recurso de inconstitucionalidad contra leyes y normas con fuerza de ley del Estado y de las Comunidades Autónomas o contra tratados internacionales». Se procedía, pues, a un reconocimiento expreso del control judicial de constitucionalidad de los tratados en vigor, confundiendo su régimen con el del control de la constitucionalidad de las leyes. Este proyectado artículo cubrió en paz la singladura del Congreso, pero ya en el Senado su supervivencia se vio amenazada $\mathrm{y}$, finalmente, decayó. Factor desencadenante de su desestabilización fue una sutil enmienda del grupo senatorial de UCD, tanto más sutil cuanto que estaba en línea de contradicción con la anteriormente presentada por sus correligionarios en la Cámara Baja ${ }^{49}$. Lejos de combatir frontalmente el recurso de inconstitucionalidad de los tratados, que era su objetivo, la enmienda osó presuponer que tal recurso no existía en el textó aprobado por el Congreso. Yendo contra la misma evidencia aportada por el tenor literal del -ahora- artículo 155.1.a, se atrevió a identificar la alusión al recurso de inconstitucionalidad contra tratados internacionales con el requerimiento de calificación auténtica previsto por el vigente artículo 95.2 de la Constitución. Sobre esta plataforma bien podía discurrir con desahogo argumentando que ni la terminología ni la localización de la referencia eran las más correctas y sugerir clarificaciones de verbo y una sede más apropiada, a saber: sacar a los tratados del apartado en que se establecía el recurso de inconstitucionalidad de las leyes y asentar en apartado independiente la com-

47 Véanse las decisiones del Consejo Constitucional de 19 de junio de 1970 y 30 de julio de 1976; contra, en posición aislada, Cl. Blumann, op. cit., págs. 569 y sigs.

${ }_{48}$ Enm. núm. 779 (UCD). De acuerdo con ella, el entonces art. 152.a debía concretar que el recurso de inconstitucionalidad abarcaba a las leyes $\mathrm{y}$ normas con fuerza de ley del Estado y de las Comunidades Autónomas, así como... los tratados internacionales.

${ }_{49}$ Enmienda in voce (Comisión, «D. de S.», 14 de septiembre de 1978, núm. 55) sustitutiva de la enm. núm. 762 , en la que para nada se aludía al punto que ahora examinamos. 
petencia del Tribunal Constitucional para conocer «del dictamen de inconstitucionalidad de tratados internacionales» en los términos previstos en el entonces artículo 89 (95 de la Constitución). Las consecuencias de la modificación saltaban a la vista. Ni por los órganos legitimados para iniciar el procedimiento, ni por el momento pertinente para hacerlo, ni por los efectos de su experimentación podía confundirse este dictamen con el recurso de inconstitucionalidad que, también para los tratados, se había previsto en el proyecto aprobado por el Congreso. En la Comisión de Constitución del Senado, la denuncia del carácter altamente regresivo de la enmienda ${ }^{50}$ provocó que ésta se moviera en fuga al imperio de la confusión. El senador Valverde ofreció, en efecto, una nueva redacción -aprobada por menguado margen en la Comisión y luego en el Pleno-, según la cual, en apartado independiente, se afirmaría la competencia del Tribunal para conocer «de la declaración de inconstitucionalidad de los tratados internacionales» (art. 160.1.b del texto aprobado por el Senado). Suprimido el recordatorio del vigente artículo 95, transformado el dictamen en declaración, separado éste del recurso de inconstitucionalidad, ¿estábamos acaso ante un tertius genus del que nadie sabía nada, ante una improvisación vaporosa? El enmendante quería hacer jugar a la doctrina al damero maldito. Su afirmación de que con la nueva redacción se dejaba abierta solamente la posibilidad de combatir «un tratado del pasado que sea inconstitucional» era gratuita. ¿Cuáles eran los términos que consentían excluir a los tratados del futuro? Pero tampoco el texto del Senado fue definitivo. El último golpe correspondió a la Comisión Mixta Congreso-Senado. Teniendo que elegir entre los diferentes textos adoptados por una y otra Cámara, se decidió por la supresión de ambos, y así, de tener dos preceptos que preveían un cierto control judicial de la constitucionalidad de los tratados, se pasó a no tener ninguno, singular manera de entender la acomodación entre textos discrepantes. De una regulación discutible, pero conocida, se pasó a una regulación incógnita. La falta de transparencia de la Comisión nos dejaba ayunos de explicación pública y autorizada de la supresión. Naturalmente, las interrogantes se hicieron a la mar: ¿estaban o no los tratados sujetos al control de constitucionalidad una vez publicados y en vigor? ¿Debían entenderse englobados por el artículo 161.1.a, cuando establecía en términos amplios la procedencia del recurso de inconstitucionalidad "contra leyes y disposiciones normativas con fuerza de ley»?

La Constitución no prohibía, no prohíbe, la implantación de un control reparador de la constitucionalidad de los tratados internacionales. A partir de ahí un buen número de los comentaristas de la ley fundamental estimó que su aceptación estaba implícita en el artículo 161.1.a ${ }^{51}$, al menos por lo que se

so Sainz de Varanda («D. de S.», 14 de septiembre de 1978, núm. 55).

${ }^{51}$ O. Alzaga, op. cit., pág. 597, la da por supuesta en su comentario al art. 95 de la Constitución, pero se muestra más dubitativo - págs. 927-928-en su exégesis del art. 161. S. Galeotti y B. Rossi (El Tribunal Constitucional en la nueva Constitución española: medios de impugnación y legitimados para actuar, «R. E. P.», 1979, núm. 7 -nueva época-, pág. 122), se inclinan por la extensión del control de constitucionalidad, previsto por el art. 161.1.a, a los tratados internacionales que en virtud del art. 96 forman parte directamente del ordenamiento interno y están equiparados a las leyes. También acoge este argumento J. González Pérez, op. cit., pág. 80. F. Santaolalla (Los tratados como fuente del Derecbo en la Constitución, «R. A. P.», núm. 90, págs. 19-20 - también en 
refiere a los tratados cuya conclusión había sido objeto de autorización parlamentaria ${ }^{52}$.

Los negadores se hicieron fuertes en el artículo 96.1 de la Constitución, alli donde el precepto afirma que las disposiciones de un tratado en el que sea parte España «sólo podrán ser derogadas, modificadas o suspendidas en la forma prevista en los propios tratados o de acuerdo con las normas generales del Derecho internacional». Una declaración de incompatibilidad sería, se ha dicho ${ }^{53}$, inconciliable con esta disposición. Concluyen demasiado, prescindiendo de lo que dice el mismo artículo 96.1. Las cláusulas que no pueden ser derogadas, modificadas o suspendidas sino en la forma prevista por el Derecho internacional son las de aquellos tratados que se han incorporado al ordenamiento interno. ¿Qué tratados se han incorporado al ordenamiento interno? Los válidamente celebrados, una vez publicados oficialmente en España. Se presupone, pues, una validez constitucional susceptible - si no se dice lo contrario- de ser contrastada mediante los mecanismos de control de que dispone el sistema. La verificación de constitucionalidad será, ciertamente, extrinseca, pero también intrínseca, porque ¿cómo, en efecto, se ha podido celebrar válidamente un tratado cuyo contenido rebasa los límites materiales de la Constitución?

2. La LOTC ha despejado todas las interrogantes que dejó bailando la Constitución y ha tomado partido al afirmar en los términos más amplios el control a posteriori de todos los tratados internacionales (y, por supuesto, de las leyes promulgadas para su aplicación y ejecución). Ningún grupo parlamentario, diputado o senador ha discutido la opción que en este sentido hacía el proyecto de ley remitido a las Cortes por el Gobierno ni ha puesto en duda su constitucionalidad. Realmente, la única aportación parlamentaria al texto gubernamental —cuyo art. 30.c mencionaba a «los tratados internacionales, sea cual sea la forma que revista la prestación de consentimiento», entre los susceptibles de control - ha consistido en la supresión por la Ponencia del Congreso del último inciso, aclaratorio del afán globalizador que se pretendía dar a la competencia del Tribunal, pero tal vez innecesario ${ }^{54}$. Así que, finalmente, el ar-

La Constitución y las fuentes del Derecho, Dirección General de lo Contencioso del Estado, Madrid, 1979, III, págs. 1925-1926-) estima que el procedimiento del art. 95 de la Constitución es una garantía adicional a los establecidos en el título del Tribunal Constitucional, un filtro previo para evitar el recurso a procedimientos más gravosos y comprometedores, abiertos en todo caso para salvar la superioridad de la Constitución.

${ }_{52}$ Hay quienes entienden que los tratados celebrados sin autorización parlamentaria no afectan a las leyes - en otro caso su conclusión debió contar con la autorización de las Cortes- $y$, por tanto, no son cubiertos por el art. 161.1.a de la Constitución. ¿Significa acaso que sobre ellos no recae ningún tipo de control o más bien que, como los reglamentos y disposiciones infralegales, son susceptibles de ser anulados por los tribunales ordinarios por inconstitucionalidad o inacomodación con las leyes? Lo primero sería ilógico; lo segundo, excesivo. La LOTC ha despejado la interrogante sometiendo a todos los tratados al control de constitucionalidad. De necesitar un fundamento para ello, lo encuentra en el art. 161.1.d de la Constitución, que permite mediante ley orgánica extender las materias competencia del Tribunal.

${ }_{53}$ Véase J. Almagro Nosete, Justicia constitucional..., cit., pág. 347; íd., Poder Judicial y Tribunal de Garantías en la nueva Constitución, en Lecturas sobre la Constitución española, I, págs. 339-340. También L. Sánchez Agesta, op. cit., pàg. 383.

${ }_{54} \mathrm{La}$ única enmienda al texto del proyecto fue formulada por el Grupo Andalucista (enm. núm. 218). De acuerdo con ella, había de aludirse a «los tratados y acuerdos interna- 
tículo 27.2.c de la ley, de manera tan escueta como total, ha dispuesto que son susceptibles de una declaración de inconstitucionalidad «los tratados internacionales». El texto de este artículo - confirmado por el del 32.1- es tan claro e inequívoco que sorprende el que algún autor haya sostenido lo contrario ${ }^{55}$ con argumentos sensibles a las exigencias del orden internacional que bien pudieron ser tenidas en cuenta - pero no lo fueron- en la fase de su elaboración. Gusten o no estas disposiciones, son hoy el Derecho vigente y se apoyan en una doble cobertura constitucional. De una parte, el artículo 161.1.a ampara el control de los tratados cuya conclusión contó con la previa autorización de las Cortes. De otra, el artículo 161.1.d, al permitir que mediante ley orgánica - y la del Tribunal lo es- se ensanche su competencia objetiva, ofrece una generosa sombrilla tanto a estos como sobre todo a los restantes tratados.

La declaración de inconstitucionalidad de los tratados internacionales, al igual que la de los demás textos susceptibles de control por esa jurisdicción especial y concentrada que es el Tribunal Constitucional, se podrá promover por una de estas dos vías: 1) el recurso de inconstitucionalidad (art. 29.1.a), de índole abstracta, que están legitimados a ejercitar el presidente del Gobierno, el Defensor del Pueblo, cincuenta diputados o cincuenta senadores, así como, en la medida en que el tratado afecte a su propio ámbito de autonomía, las asambleas y órganos colegiados ejecutivos de las Comunidades Autónomas (arts. 162.1 a de la Constitución y 32 de la LOTC), y 2) la cuestión de inconstitucionalidad (art. 29.1.b), de índole concreta, que un juez o tribunal, de oficio o a instancia de parte, planteará cuando considere que la norma convencional de cuya validez depende el fallo del litigio de que está conociendo puede ser contraria a la Constitución (arts. 163 de la ley fundamental y 35.1 de la LOTC).

El recurso de inconstitucionalidad contra un tratado internacional puede promoverse dentro de los tres meses siguientes a su publicación oficial - fecha determinante de su incorporación y aplicabilidad en el orden interno (arts. 96.1 de la Constitución y 1.5 del Código civil) - mediante demanda presentada por quienes disponen de legitimación activa ante el Tribunal Constitucional (arts. 31 y 33 de la LOTC). La lista de los legitimados no satisfará a todos por demasiado amplia o, al contrario, por demasiado estrecha, pero es en su conjunto aceptable. Ser más restrictivo arriesgaría vaciar de contenido el recurso; ser más abierto comprometería un ejercicio responsable del mismo y el carácter de una decisión que ha de estar dotada de la mayor autoridad formal. En un examen más particularizado cabrían las siguientes observaciones: 1) a diferencia de lo que sucede en la experimentación del control previo, donde se legitima al Gobierno (arts. 95.2 de la Constitución y 78.1 de la LOTC), el

cionales, sea cual sea la forma que revista la prestación del consentimiento, así como la personalidad de quien lo otorga», con el fin de que quedara bien claro que eran fiscalizables los «acuerdos denominados ejecutivos» y también «los que se pacten por las Comunidades Autónomas, órganos de la Administración del Estado, entidades autónomas, etc.». Lo primero era superfluo. Lo segundo - que planteaba la delicada cuestión del ius ad tractatum de las Comunidades Autónomas-, difícilmente asimilable política y jurídicamente en ese momento (véase sobre el particular mi trabajo La actividad exterior del Estado $y$ las Comunidades Autónomas, en Estudios sobre la Constitución española de 1978, ed. M. Ramírez, 1979, págs. 355 y sigs.). La ponencia rechazó la enmienda andalucista. 
legitimado para iniciar este control reparador es su presidente (normalmente otro y no aquel bajo cuyo mandato se concluyó el tratado recurrido). No hay, seguramente, razones que avalen la distinción, pero en todo caso sus consecuencias prácticas serán poco apreciables, y no es éste, ni mucho menos, el único supuesto en que la misma Constitución reconoce al presidente iniciativas sujetas a su discreción y no a la del Gobierno como tal (véanse, por ejemplo, los artículos 62.g y 92.2); 2) la inclusión entre los órganos legitimados para el ejercicio del recurso de inconstitucionalidad del Defensor del Pueblo, alto comisionado de las Cortes, según el artículo 54 de la Constitución, cuya misión és supervisar la actividad de la Administración para la defensa de los derechos fundamentales comprendidos en el título I de la ley fundamental, llama la atención tanto como la omisión del Ministerio Fiscal, a quien corresponde (art. 124.1 de la Constitución) «promover la acción de la justicia en defensa de la legalidad, de los derechos de los ciudadanos y del interés público tutelado por la ley». Por lo que se refiere al Defensor del Pueblo ha de entenderse su legitimación implícitamente circunscrita por la misión que se le atribuye ${ }^{56}$; podrá, en consecuencia, ejercitar el recurso sólo frente a los textos susceptibles de declaración de inconstitucionalidad, entre ellos los tratados que en su opinión perjudiquen los derechos humanos fundamentales reconocidos por la Constitución. En cuanto al Ministerio Fiscal no faltan esfuerzos para tenerlo por legitimado, a pesar de no ser mencionado por la Constitución ni por la LOTC, atendiendo a su papel de cancerbero de la legalidad ${ }^{57}$. En mi opinión, sin embargo, la lista de órganos llamados al ejercicio del recurso es cerrada y la exclusión del Ministerio Fiscal es tan penosa como irremediable. Ello no lo reduce a la nada. Al margen de su intervención en la experimentación de la otra vía del control reparador -la cuestión de inconstitucionalidad - para plantear la cual el juez o tribunal ha de darle audiencia, el Ministerio Fiscal está legitimado para interponer recursos de amparo (arts. 161.1.b y 162.1.b de la Constitución y 41 y siguientes de la LOTC) que, eventualmente, podrían desembocar en una declaración de inconstitucionalidad de la ley o del tratado cuya aplicación viola los derechos enunciados por los artículos 14 a 30 de la Constitución; 3) no ha de considerarse bajo el número de sesenta diputados o senadores, mínimo necesario para desatar el recurso: primero, porque los parlamentarios de una y otra Cámara no pueden confundir su firma en una misma demanda, y segundo, porque actos de más graves consecuencias políticas requieren un aval más reducido (así, por ejemplo, basta con una décima parte de diputados - - en la actualidad treinta y cinco- para la presentación de una moción de censura: art. 113.2 de la Constitución). El establecimiento de un mínimo sirviéndose de un número fijo y no de un porcentaje perjudica, por

${ }_{55} \mathrm{~J}$. Almagro Nosete, Justicia constitucional..., cit., pảgs. 113 y $347-349$, para quien el control a posteriori del Tribunal Constitucional sí que abarcaría, en cambio; el acto de autorización por las Cortes de la prestación del consentimiento del Estado en los casos previstos en el art. 94 de la Constitución. Siendo equivalente esta autorización a un acto con fuerza de ley, el control se basaría en el art. 27.2.b de la LOTC. También sería susceptible de control la ley orgánica mediante la que se autorice la celebración de un tratado conforme al art. 93 de la Constitución.

${ }_{56} \mathrm{~J}$. A Arozamena, op. cit., pág. 165.

${ }_{5} \dot{M}$. Montoro, El Ministerio Fiscal ante el Tribunal Constitucional, en El Tribunal Constitucional, cit., vol. III, págs. 1916-1918. 
otro lado, al Senado en relación con el Congreso: sesenta equivale a un cuarto del total de senadores y sólo a un séptimo del de diputados ${ }^{58}$; 4) no ha de negarse la legitimación de las asambleas y órganos colegiados ejecutivos de las Comunidades Autónomas para entablar recurso contra los tratados que consideren inconstitucionales por hollar su ámbito de autonomía. Ajustándose a la letra del artículo 32 de la LOTC, hay quien ha advertido que, en tanto el número 1 menciona expresamente a los tratados internacionales al perfilar la legitimación, el 2 concreta la de los órganos autonómicos en «las leyes, disposiciones o actos con fuerza de ley del Estado». No obstante, su legitimación, también respecto de los tratados, se apoya en varias consideraciones. Primera: el artículo 162.1.a de la Constitución enumera a los órganos autonómicos entre los legitimados para interponer el recurso de inconstitucionalidad que, según el artículo 161.1.a, cabe contra «leyes y disposiciones normativas con fuerza de ley». Este precepto es fundamento del control de constitucionalidad de los tratados internacionales establecido por el artículo 27.2.c de la LOTC y, por tanto, en la misma medida, le es aplicable lo dispuesto en el artículo 162.1.a de la ley fundamental, no teniendo la LOTC rango suficiente para coartar una facultad que la misma Constitución otorga. Segunda: los Estatutos de Autonomía forman parte del bloque de constitucionalidad, y nadie más interesado en su salvaguarda que los órganos legislativos y ejecutivos de las Comunidades. Y tercera: los objetivos del control tendrían una expectativa de satisfacción menor si tal legitimación se limita o se desconoce allí precisamente donde la realidad ha de plantear conflictos; 5) no cabe la acción popular; los particulares quedan al margen del recurso. Sin embargo, aparte del papel que como partes en un proceso puedan representar en el planteamiento de una cuestión de inconstitucionalidad por el juez o tribunal ante el que pende el litigio, los particulares tienen abierta la puerta del Defensor del Pueblo, pudiendo instarle a la interposición de un recurso ${ }^{9}$. Por otro lado, a través de la interposición de un recurso de amparo (arts. 161.1.b y 162.1.b de la Constitución; 44 y siguientes de la LOTC), un particular agraviado podría, en determinados casos, obtener la declaración de inconstitucionalidad de la ley o del tratado cuya aplicación está lesionando derechos que le son reconocidos en los artículos 14 a 30 de la ley fundamental (art. 55.2 de la LOTC) ${ }^{60}$.

La segunda vía para controlar la conformidad con la Constitución de un tratado internacional vigente $\mathrm{y}$ aplicable se abre a través del planteamiento de lo que la LOTC, con poco ángel, ha denominado una cuestión de constitucionalidad, expresión acarreada en el Senado y, finalmente, preferida a la ofrecida en el proyecto de ley (art. 32) e inicialmente aceptada por el Congreso, que distinguió entre el recurso de inconstitucionalidad por vía principal o di-

\$s Véase F. Rubio y M. Aragón, op. cit., pág. 832.

59 J. González Pérez, op. cit., pág. 253, advierte la denegación de justicia que, en su opinión, supone privar de legitimación al ciudadano, para paliar la cual, dice, en la ley orgánica del Defensor del Pueblo debería imponérsele la iniciación del proceso constitucional en virtud de denuncia, salvo que fuese manifiesta la improcedencia de la inconstitucionalidad. La ley no ha hecho tal cosa, Véase también sobre este punto V. Fairen, Algunos problemas procesales que plantea la ley orgánica del Tribunal Constitucional español, en El Tribunal Constitucional, cit., vol. II, págs. 1003-1007.

- Véase E. García de Enterría, La Constitución como norma y el Tribunal Constitucional, Madrid, 1981, págs. 150-151; J. Arozamena, op. cit., págs. 148-149 y 167. 
recta y el recurso de inconstitucionalidad por la vía incidental. El órgano legitimado para plantear la cuestión es el juez o tribunal ante el que está pendiente un litigio cuyo fallo depende de la validez de la norma cuya constitucionalidad se cuestiona. El juez o tribunal no puede descartar la aplicación de un tratado - si de un tratado se trata- por estimarlo inconstitucional, pero tampoco está obligado a sorber sus propias dudas o a pasar por su propio criterio aplicando un tratado de cuya inconstitucionalidad sospecha o hasta está convencido. Se evita un control de constitucionalidad difuso, puesto en manos de los jueces ordinarios, pero se da paso a la iniciativa judicial en el funcionamiento de un control de constitucionalidad concentrado, encomendado al Tribunal Constitucional. Las partes en el litigio disponen de dos derechos: el de instar el planteamiento de la cuestión - que se reproduce de una instancia o grado a la sucesiva - y el de ser oído, junto con el Ministerio Fiscal, antes de que el juez o tribunal adopte una decisión definitiva. Pero no tienen legitimación y tampoco pueden forzar al juez o tribunal -facultado también a proceder de oficio- a que lo haga. La razón de esta limitación que no a todos convence hay que buscarla en el deseo de impedir que esta vía de control sea explotada como una maniobra o estratagema dilatoria, un propósito que se palpa en otros muchos aspectos de la regulación, como la fijación del momento en que es posible plantear la cuestión ( «una vez concluso el procedimiento y dentro del plazo para dictar sentencia»), el plazo de audiencia de las partes y del Ministerio Fiscal («común e improrrogable de diez días») y el de la decisión del juez o tribunal (que se producirá «seguidamente y sin más trámite en el plazo de tres días») o el carácter irrecurrible de ésta, que tomará la forma de auto (arts. 163 de la Constitución y 35 de la LOTC).

3. Los tratados internacionales concluidos y publicados oficialmente después de la formación y puesta en funcionamiento del Tribunal Constitucional son objeto, obviamente, de los controles reparadores de constitucionalidad que estamos considerando. Otro tanto ocurre con los tratados celebrados después de la promulgación de la Constitución y publicados antes de que el Tribunal comenzara a ejercer sus funciones. La disposición transitoria segunda, 1, de la LOTC, según la cual «los plazos previstos en esta ley para interponer el recurso de inconstitucionalidad... comenzarán a contarse desde el día en que quede constituido el Tribunal... cuando las leyes, disposiciones, resoluciones o actos que originen el recurso... fueran anteriores a aquella fecha y no hubieran agotado sus efectos», les es, desde luego, aplicable. Ese plazo, de tres meses, se ha agotado sin que tales recursos hayan llegado a interponerse; no obstante, de cara al futuro queda expedita la vía para el planteamiento de una cuestión de constitucionalidad. ¿Cabe acaso decir lo mismo en relación con los tratados estipulados y publicados con anterioridad a la misma Constitución? Para responder adecuadamente a esta interrogante - de particular interés en un país que, como el nuestro, se ha dado una nueva carta magna en diciembre de 1978- lo primero que habría que decidir es si el tratado anterior cuyo contenido aparece como realmente incompatible con la nueva ley fundamental, posterior a su conclusión, plantea un problema de inconstitucionalidad sobrevenida o bien un problema de derogación por ley posterior que además tiene un rango superior. En el primer caso, la disposición transitoria segunda, 1, de la LOTC - -que no distingue a las leyes (y, por extensión, a los tratados) según 
la fecha en que se produce su inconstitucionalidad- encauzaría su sujeción a los controles reparadores arbitrados por el Tribunal Constitucional ${ }^{61}$; en el segundo, la situación sería mucho más compleja, al ser preciso fijar el alcance e identificar el órgano llamado a aplicar la derogación de «cuantas disposiciones se opongan a lo establecido en esta Constitución» que, con indefinida generalidad, proclama la ley fundamental (disposición derogatoria núm. 3).

Según la opinión general, la disposición derogatoria (núm. 3) alcanza a todas las disposiciones cuyo contenido esté en irreductible oposición con los preceptos constitucionales, incluidos aquellos que se limitan a plasmar principios orientativos ${ }^{62}$. La atribución de competencia para proceder a su aplicación ha sido, en cambio, más discutida. Atendiendo a consideraciones prácticas, como la de favorecer la unicidad sobre la dispersión, la seguridad sobre la incertidumbre, la probabilidad de acierto y moderación sobre la de error y radicalismo, que ofrece una jurisdicción concentrada y especializada, se ha sostenido que -a salvo las normas constitucionales de indiscutible aplicación directa, esto es, las que afectan a los derechos fundamentales y a la organización, competencia y funcionamiento de los poderes, cuya eficacia derogatoria es apreciada por cualquier órgano de aplicación del Derecho- correspondía al Tribunal Constitucional el examen de compatibilidad entre la norma anterior y la Constitución. La derogación, se ha dicho, pasa por un juicio previo de inconstitucionalidad, y ese juicio tiene exactamente el mismo contenido tanto si la ley contrastada es posterior como si es anterior a la Constitución ${ }^{63}$. Pero este punto de vista, próximo a la solución dada al mismo problema por el Tribunal Constitucional italiano, ha sido combatida buscando inspiración en la experiencia alemana. Y así, se ha advertido que las diferencias en conceptuación, causas y efectos existentes entre inconstitucionalidad y derogación debían conducir a una completa separación de los órganos facultados y obligados a apreciarlas. La inconstitucionalidad podía afectar a las disposiciones posteriores a la Constitución y desembocaba en una declaración de invalidez con valor erga omnes de las mismas, formalmente vigentes; correspondía, con carácter exclusivo, al Tribunal Constitucional. La derogación afectaba a disposiciones anteriores a la Constitución y conducía a la pérdida de vigencia de normas que eran válidas; incumbía su apreciación a los órganos judiciales ordinarios que, en el caso concreto, dejarían de aplicar las disposiciones derogadas. El juicio de derogación presuponía la incompatibilidad insalvable de la norma anterior con la ley fundamental, pero nada impedía a jueces y tribunales proceder a tal examen en la medida necesaria para decidir sobre aquél. El Tribunal Constitucional era

${ }^{61}$ Esta respuesta no ofrecería la menor duda en el caso de que se hubiese adoptado en sus mismos términos la enm. núm. 66 (G. Socialista), que especificaba que el plazo para la interposición de un recurso de inconstitucionalidad sería de seis meses a partir de la fecha de constitución del Tribunal para las leyes y disposiciones normativas con fuerza de ley publicadas con anterioridad a la fecha de promulgación de la Constitución.

${ }_{62}$ La sentencia del Tribunal Constitucional de 2 de febrero de 1981 lo afirma taxativamente: tratándose de incompatibilidad entre una disposición legal y un principio constitucional, la apreciación será más difícil y delicada; pero, de darse aquélla, la fuerza derogatoria del principio no es menor que la de un precepto constitucional con un contenido normativo más preciso. En la doctrina, F. Garrido Falla (Comentarios a la Constitución, Madrid, 1980, pág. 1977) había sostenido una postura restrictiva.

${ }^{63}$ Véase E. García de Enterría, La Constitución como norma..., cit., págs. 83-94. 
-es- el intérprete supremo de la Constitución, pẹro no el único, y en parte alguna se había dispuesto la sustracción de la facultad que se reconoce a jueces y tribunales para apreciar el efecto derogatorio de la lex posterior atendiendo a su rango de norma fundamental ${ }^{64}$. No obstante, esta posición tampoco ha prosperado en sus mismos términos. Se ha aceptado, desde luego, y la práctica la confirma ${ }^{65}$, la competencia de los órganos judiciales ordinarios para aplicar en toda su extensión la disposición derogatoria, pero se ha rechazado que esa competencia sea exclusiva ${ }^{60}$. De hecho se ha ido afirmando - hasta contar hoy con el respaldo del Tribunal Constitucional (sentencias de 2 de febrero y 8 de abril de 1981) _ una alternatividad cuyo juego real está sujeto a la discreción de jueces y tribunales que, si bien pueden resolver por sí mismos el juicio de derogación, también pueden, en el caso de sustentar dudas acerca de la premisa en que tal juicio descansa, plantear la cuestión al Tribunal Constitucional, el cual, respondiendo al papel que le corresponde, podría estimar la inconstitucionalidad y con valor erga omnes y carácter definitivo declarar la nulidad y la derogación de la disposición cuestionada ${ }^{67}$. Esta conclusión tendría suma trascendencia en el caso de que los tratados anteriores a la Constitución e incompatibles con ella estuvieran incursos en la disposición derogatoria. No hay tal, en mi opinión. Y ello en virtud de lo dispuesto en el artículo 96.1 de la misma ley fundamental, ségún el cual la derogación de las disposiciones de un tratado internacional válidamente celebrado - validez formal que, en todo caso, se ha de analizar conforme a las leyes vigentes al tiempo de la celebración (tempus regit actum) - sólo podrá realizarse conforme a lo previsto en el propio tratado o en las normas generales del Derecho internacional. De aceptarse este planteamiento, habrá de descartarse la eventualidad de que jueces y tribunales ordinarios procedan a la inaplicación de tratados internacionales vigentes en el momento de promulgarse la Constitución en la medida en que, estimando la oposición de.sus estipulaciones a la ley fundamental,

${ }^{64}$ Este punto de vista ha sido vigorosamente sostenido por F. Rubio en su voto particular a la sentencia del Tribunal Constitucional de 2 de febrero de 1981. Lo comparte M. Aragón, Dos cuestiones interesantes en nuestra jurisdicción constitucional: control de las leyes anteriores y de la jurisprudencia, en El Tribunal Constitucional, cit., vol. I, págs. 565-570; también en el comentario a la mencionada sentencia del Tribunal Constitucional en la REDC, 1981 , págs. $185-205$, con ciertas matizaciones: aunque la LOTC no había previsto el supuesto, los órganos judiciales ordinarios podrían plantear sus dudas definitivas acerca de la incompatibilidad entre norma anterior y Constitución ante el Tribunal Constitucional, al objeto de establecer su decisión sobre la derogación de aquélla. Aragón intenta fijar las diferencias entre esta consulta y el planteamiento de una cuestión, ofreciendo fórmulas para llevarla a cabo dentro del marco legal vigente.

${ }^{\circ 5}$. Véase L. Prieto, Dos años de jurisprudencia del Tribunal Supremo sobre cuestiones constitucionales, REDC, 1981, págs. 228-234.

${ }^{6}$ Véanse J' Arozamena, op. cit., págs. 161-162; P. de Elizalde, El Tribunal Constitucional y la jurisprudencia, en El Tribunal Constitucional, cit., vol. I, págs. 870-871; J. González Pérez, La cuestión prejudicial de inconstitucionalidad, ibíd., págs. 1229-1231 (rectificando su previa postura favorable a la competencia exclusiva del Tribunal Constitucional: Derecho procesal..., cit., pág. 65); G. Peces-Barba, op. cit., pág. 2065.

${ }_{67} \mathrm{~A}$ esta aproximación cabe oponer reparos de orden lógico y práctico. Véanse los comentarios a la sentencia del Tribunal Constitucional de 2 de febrero de 1981: M. Aragón, en REDC, 1981, págs. 185 y sigs.; L. Parejo, en «R. A. P.»; 1981; F. Lorente, en «La Ley», 12 de junio de 1981, núm. 180. Véase también E. García de Enterría, La Constitución como norma..., cit., págs. 92-93. 
las consideren derogadas. Ahora bien: aunque la disposición derogatoria no alcance a los tratados internacionales, ¿no sobreviene, ineluctable, su inconstitucionalidad? ¿Cabe negar una incompatibilidad que se deduce de la mera comparación entre dos textos, por más que la ley posterior y superior haya salvado de la derogación a la primera? ¿Cómo ha de afrontarse esta inconstitucionalidad sobrevenida?

En el orden internacional, los cambios del Derecho interno, por importante y constitucional que sea su rango, no consienten por sí solos a los Estados ampararse en ellos para justificar el incumplimiento de un tratado ${ }^{68}$. Servirán, en su caso, como metralla de ciertas causas de nulidad y sobre todo terminaciórr de los tratados. De ahí que una clara conciencia de los problemas que se derivan del posible conflicto entre el Derecho internacional y el Derecho del Estado hubiera hecho sabia la previsión de una disposición transitoria -entre el frondoso racimo de las aprobadas por los constituyentes- que dispusiera que los preceptos de la Constitución no afectarían a la observancia de los tratados suscritos con anterioridad, aunque exigiendo al Gobierno en caso de incompatibilidad la experimentación de los medios que permitan su revisión o terminación en el orden internacional. Nada de esto se hace en la Constitución española. Por el contrario, en nuestro proceso constituyente han sido los tratados concluidos durante el régimen del general Franco los que han estado en la mente de quienes defendían el control de constitucionalidad y han animado su debate parlamentario. $\mathrm{Y}$ el artículo 160.1.b del proyecto aprobado por el Senado aspiraba a salvar, según su proponente, el control de los tratados del pasado y de ellos sólo ${ }^{\theta}$. Con una óptica doméstica era explicable esta aproximación al problema. En el orden interno, sea cual sea la responsabilidad internacional en que se pueda incurrir, existe una tendencia irresistible a hacer prevalecer la norma constitucional cuando ésta - como es el caso español- no es la consecuencia de una reforma parcial en el marco de un sistema invariable, sino que refleja el paso de un régimen político autoritario a otro formalmente democrático y representativo. En estas circunstancias, el hecho de que el contenido de un tratado, concluido sin contar con la autorización - que no era necesaria - de los representantes del pueblo, se oponga o esté en contradicción con los principios fundamentales que ahora inspiran al Estado genera - particularmente cuando el tratado es importante- una indomable inclinación a su inobservancia. No hay precepto que obstaculice la competencia del Tribunal Constitucional para controlar la inconstitucionalidad sobrevenida de los tratados vigentes al promulgarse la Constitución. La disposición transitoria segunda, 1, de la LO'TC es aplicable por cuanto se refiere a las leyes y disposiciones anteriores a la fecha de formación del Tribunal sin distinguir entre ellas. Transcurridos tres meses desde esa fecha sin que se hayan interpuesto recursos contra dichos tratados, queda abierto en adelante el planteamiento de cuestiones por los órganos judiciales que conozcan de litigios cuyo fallo dependa de la validez de uno de esos tratados.

4. Cuando una sentencia estima o declara la inconstitucionalidad de una

${ }^{63}$ Art. 27 de la Convención de Viena sobre Detecho de los Tratados de 23 de mayo de 1969.

${ }_{69} \ll \mathrm{D}$. de S.», 14 de septiembre de 1978, núm. 55. 
norma es ocioso preguntarse por su eficacia preclusiva de ulteriores recursos o cuestiones sobre el mismo objeto. La sentencia, al anular la norma, lo ha volatilizado. Pero, por el contrario, cuando la decisión del Tribunal es desestimatoria, cobra un profundo interés, una enorme trascendencia, la consideración de si es o no posible la interposición de nuevos recursos o el planteamiento de (nuevas) cuestiones por quienes, legitimados para ello, esperan que un cambio de circunstancias, una inversión de la mayoría, el transcurso del tiempo o una diferente interpretación de la norma cuestionada provoquen la modificación, la evolución del criterio del Tribunal. La LOTC no ha estado, sin embargo, a la altura correspondiente al interés y trascendencia del tema; la regulación que ofrece es poco coherente, muy desdichada, y la doctrina, como era de esperar, se ha levantado en plumas contra ella, estimándola en general estrecha y restrictiva, ignorante del carácter de la justicia constitucional - tan distante del propio de la justicia civil_, absurda y, al cabo ya, inconstitucional. Para su más claro y provechoso examen es conveniente que distingamos varios supuestos, según se trate de interposición de recurso o planteamiento de cuestión sobre una norma cuya inconstitucionalidad ha sido previamente desestimada por vía de recurso en el primer caso o por vía de recurso o de cuestión en el segundo.

El primer supuesto recibe una directa y simple - aunque no inobjetablesolución legal. En efecto, según el artículo 38.2 de la LOTC, desestimado un recurso de inconstitucionalidad serán procedentes ulteriores recursos sobre el mismo objeto con tal de que cambie su fundamento, esto es, el precepto constitucional que se considere infringido ${ }^{70}$. Teniendo en cuenta que el plazo de que se dispone para la interposición de los recursos es reducido estaría en principio justificado, desde el ángulo de la justicia constitucional, el rechazamiento de aquellos que sean estricta reproducción - mismo objeto, mismo fundamento- de los desestimados, porque es harto improbable una rectificación del criterio del Tribunal en tan corto lapso de tiempo. Ahora bien: esta explicación, válida para las sentencias desestimatorias que afirman la conformidad de la norma impugnada con la Constitución, no lo es para aquellas otras en que la desestimación ha sido motivada por defectos de forma que han impedido precisamente entrar en ese examen de conformidad. ¿Por qué no permitirlo una vez que tales defectos han sido subsanados? Esa es la interrogante que, tal como está redactado, el artículo 38.2 de la LOTC no sabe contestar afirmativamente, y ahí se localiza su punto más débil. De todos modos, y por la limitación del plazo de interposición, ya señalada, el supuesto de dos recursos sucesivos sobre el mismo objeto, con el mismo o diferente fundamento, será verdaderamente excepcional.

El segundo supuesto contempla el planteamiento de cuestión acerca de una norma cuya inconstitucionalidad, debatida por vía de recurso, ha sido previamente desestimada. El proyecto de ley remitido por el Gobierno a las Cortes lo admitía en los términos más amplios, aceptando incluso aquellas cuestiones

70 El proyecto de ley rechazaba en términos absolutos el ulterior recurso sobre norma cuya inconstitucionalidad hubiese sido desestimada como consecuencia de un recurso anterior (art. 42.2, segundo inciso). Pero la Ponencia tuvo en cuenta una enmienda (núm. 12) del Grupo Socialista para corregir, atenuando, esta posición. Con ligeros cambios de redacción es el art. 38.2 de la Ley. 
con idéntico fundamento al del recurso desestimado: «La desestimación de un recurso de inconstitucionalidad», decía el artículo 32 del proyecto, «... no será obstáculo para que la misma ley, disposición o acto puedan ser impugnados en vía incidental». Pero esta propuesta no fue bien recibida en el Congreso. Argumentando que su mantenimiento abriría peligrosamente la puerta a la inseguridad jurídica, se formularon enmiendas de supresión cuyo propósito era impedir radicalmente el planteamiento de cuestiones de inconstitucionalidad una vez que el Tribunal, como resultado de un recurso, había pronunciado sentencia desestimatoria ${ }^{71}$, así como enmiendas dirigidas a limitar tales cuestiones a aquellos casos en que la desestimación se hubiera producido «por razones de forma» ${ }^{72}$. Esta última sugerencia, aceptada por la ponencia, fue la que, finalmente, hizo cuerpo en la ley (art. 29.2). El Senado trató, sin éxito, de combatirla, volviendo a los principios del proyecto: la jurisprudencia del Tribunal Constitucional, advirtió en su mensaje a la Cámara Baja, ha de adecuarse a «las exigencias de la sociedad», y por ello debe evitarse que «un requisito procesal impida a dicho Tribunal... tener en cuenta datos normativos, sociológicos o históricos nuevos o de nueva relevancias ${ }^{73}$. En el Congreso, el argumento cosechó nueve votos a favor y la enmienda senatorial fue rechazada por amplísimo margen. Hay que impedir, se dijo, que «quede abierto el cauce para que se reproduzcan indefinidamente recursos por vía incidental», un objetivo compartido por todos los grupos parlamentarios ${ }^{74}$. El efecto fue fulminantemente restrictivo. $\mathrm{La}$ sentencia desestimatoria de un recurso bloquearía el planteamiento de una cuestión sobre el mismo objeto - sea o no idéntico su fundamentoa menos que la desestimación hubiera sido provocada por razones de forma que impidieron al Tribunal entrar en el examen de la conformidad de la norma impugnada con los preceptos constitucionales presuntamente contrariados. El artículo 38.1 de la LOTC apoyaría esta interpretación frente a la que un amplio sector de la doctrina ha tocado a rebato. Al artículo 29.2 de la LOTC se le han formulado numerosas censuras. Así, se ha señalado que: 1) es una inconsecuencia admitir la interpretación de un segundo recurso contra una norma, alegando la infracción de un precepto constitucional distinto, y no admitir una cuestión planteada en términos semejantes; 2) es igualmente inconsecuente que el pronunciamiento del Tribunal en el control previo no obstruya el posterior planteamiento de una cuestión, incluso con el mismo fundamento ${ }^{75}, \mathrm{y}$, por el con-

${ }^{71}$ Enmiendas núms. 163 (Minoría Catalana), 218 (G. Andalucista), 253 y 261 (G. Comunista). Estos grupos, consecuentemente, sostenían la posición del proyecto (art. 42.2) al establecer también la incompatibilidad entre recursos sucesivos.

${ }_{72}$ Enmienda núm, 20 (G. Socialista), algo inconsecuente con la enmienda del mismo grupo al art. 42.2, segundo inciso, del proyecto (véase nota 70 ). El hecho de que prosperaran ambas enmiendas - la una de apertura y la otra de cierre- ha desestabilizado la regulación legal en este punto.

${ }_{73}$ BOCG, Congreso, serie A, núm. 44-IV, 13 de septiembre de 1979.

${ }^{74}$ Pons Irazazábal, portavoz del Grupo Socialista («D. de S.», 19 de septiembre de 1979, núm. 30).

${ }_{75}$ Art. 79.5 de la LOTC. Según esta disposición, «el pronunciamiento en el recurso previo no prejuzga la decisión del Tribunal en los recursos que pudieran interponerse tras la entrada en vigor con fuerza de ley del texto impugnado en la vía previa». El término recursos ha de interpretarse en este caso englobando tanto a los recursos propiamente tales como a las cuestiones, pues el art. 79.5 de la Ley no hace en este punto más que introducir el art. 84.5 del proyecto de ley que hacía referencia a recursos en vía principal o directa 
trario, se vincule tal efecto a la sentencia desestimatoria de un recurso de inconstitucionalidad; 3) la constitucionalidad de una determinada interpretación de una norma no supone que cualesquiera otras interpretaciones de la misma norma sean igualmente constitucionales, presunción a la que fuerza el artículo 29.2 ; 4) la distinta legitimación para interponer recursos y para plantear cuestiones hace particularmente odiosa su incompatibilidad, pues los órganos legitimados para plantear una cuestión - y quienes pueden instarles a elloacabarían en una posición frustrada; 5) al empeñarse en el artículo 29.2 , los legisladores no han advertido que el juez constitucional desempeña una misión diferente a la del juez ordinario, que hace improcedente la traslación mecánica de la eficacia preclusiva de la sentencia tal como se entiende en el proceso civil al proceso constitucional ${ }^{76}$. El Tribunal Constitucional ha de verificar la constitucionalidad de las normas desde valoraciones que no son inmutables, y en él se quintaesencia la necesaria atención que en la interpretación ha de prestarse siempre a «la realidad social del tiempo en que (las normas) han de ser aplicadas» (art. 3.1 del Código civil). Con el artículo 29.2 se cae en el grave error de «obstaculizar una de las funciones políticas más importantes del Tribunal...: la de una interpretación evolutiva que adapte el texto de la Constitución a situaciones históricas cambiantes» ${ }^{\pi}$, una función que no es desconocida para la misma LOTC (véase el art. 13), y 6) los inconvenientes prácticos de la compatibilidad entre ambas vías - recursos y cuestiones - no han de exagetarse; están compensados por sus ventajas y pueden ser corregidos y hasta anulados. Así, por ejemplo, el temor a que una tropa sin fin de cuestiones inunde al Tribunal, reiterando presuntos conflictos sobre los que éste ya se ha pronunciado, está injustificado si se tiene en cuenta que la LOTC reconoce a las secciones la facultad de no admitir a trámite cuestiones notoriamente infundadas (art. 37.1), calificativo que podría cuadrar — según la apreciación que, caso por caso, haga la sección cuando la norma cuestionada haya sido bendecida en una sentencia precedente-. Dando un paso más, de la crítica acerca de la inoportunidad o inconveniencia del artículo 29.2 de la LOTC se ha pasado a la denuncia de su inconstitucionalidad, manifiesta por cuanto, se dice, «asigna valor erga omnes a la sentencia del Tribunal que desestima el recurso por razones de fondo cuando es patente que ese efecto... está reducido expresamente en el artículo 164 de la Constitución a las sentencias que declaren la inconstitucionalidad de la ley y no a las que no la declaren»" ${ }^{78}$.

De momento, el artículo 29.2 de la LOTC sigue ahí. Los tres meses posteriores a la publicación de la ley han transcurrido sin que se hayan interpuesto recursos de inconstitucionalidad contra esta. disposición -que contó con una ancha base de apoyo en el Congreso-; por otra parte, teniendo en cuenta los

-hoy recursos- y a recursos en via incidental -hoy cuestiones-. Sería incorrecto servirse de la posterior modificación de la terminología, no reflejada en el art. 79.5 , para poner en entredicho la posibilidad de admitir el planteamiento de una cuestión tras una decisión desestimatoria dictada por el Tribunal en un recurso previo.

${ }_{76}$ Véase en este sentido, particularmente, J. Arozamena, op. cit., págs. 167-177.

${ }^{77}$ E. Gatcía de Enterría, La Constitución como norma..., cit., págs. 141-142.

${ }^{78}$ E. García de Enterría, Curso..., cit., págs. 153-154; también pág. 158. Véase además J. González Pérez, Derecbo procesal..., cit., pág. 267, y J. M. Rodríguez Oliver, Los ámbitos exentos del control del Tribunal Constitucional español, en El Tribunal Constitucional, cit., vol. III, págs. 2343-2344. 
límites dentro de los que se concibe (art. 35.1) el planteamiento de las cuestiones de inconstitucionalidad, es difícil imaginar que pueda ser objeto de una de ellas. En estas circunstancias, el argumento de su inconstitucionalidad desvía su energía al servicio de la rebelión frente a la norma. Para unos se trata de reinterpretarla; para otros, sencillamente, de ignorarla. En el primer sentido, más obsequioso con las formas, se busca sortear, sin mover, al artículo 29.2. Rubio y Aragón, sirviéndose de razonamientos lógicos y sistemáticos, se han distinguido en la ardua tarea de reeducación del precepto, que acabarían convirtiéndolo, como por arte de magia u oficio de prestidigitación, en la más inesperada y sorprendente afirmación de la admisibilidad general del planteamiento de cuestiones sobre normas cuya inconstitucionalidad fue desestimada por vía de recurso ${ }^{79}$. Aun reconociendo ingenio, esfuerzo y ánimo constructivo en su reinvención del artículo 29.2, es indudable que para llegar a este resultado se ha de pasar por encima no sólo de su letra, sino también de su espíritu, y hasta de la ley de la gravedad, si es que tiene algo que ver con este asunto. Ha de recordarse que la mens legis tradujo exactamente lo que deseaba y estaba en la mens legislatoris, por desacertada que le parezca al comentarista, y que, en consecuencia, una interpretación ajustada a los criterios sentados por el artículo 3.1 del Código civil no permite llegar a la conclusión que se nos ofrece. Parece, pues, más práctico, por más cómodo, al ofrecer menos flancos a una abierta polémica, olvidarse del artículo 29.2, condenarlo tácitamente a la muerte civil, hacer como si no existiera y, a partir de ahí, alcanzar la meta propuesta gracias a una interpretación a contrario del artículo 38.2 de la LOTC. Un obiter dictum de la sentencia de 2 de febrero de 1981 invita a creer en la predisposición del Tribunal Constitucional a seguir este camino ${ }^{80}$. Pero ¿será correcto que lo haga sin pronunciar antes la inconstitucionalidad del artículo 29.2? Las equivocaciones de la ley, ¿no deben ser corregidas por los legisladores? Y si éstos insisten en equivocarse sin ir contra la Constitución ni ser su regulación de imposible cumplimiento, ¿no es obligación de todos los órganos de aplicación del Derecho, comenzando por el Tribunal Constitucional, atenerse a sus mandatos? Si la equivocación se ba becho ley, la convicción del error de la regulación habrá de sembrarse en los campos de su reforma, de la ley por hacer, y no ser utilizada para enmendar la plana a los depositarios de la competencia legislativa considerando que su producto es absurdo. Mi ingenua actitud tiene también, por supuesto, algo de interesado. La aplicación de controles reparadores a los tratados internacionales es contemplada con desconfianza, si no con hostilidad, desde una perspectiva internacional. Cualquier restricción en su empleo es, desde esa misma perspectiva, bien venida, y ha de serlo, por tanto, la conservación y estricta observancia de una disposición como la del artículo 29.2 de la LOTC, aunque parezca lamentable desde la perspectiva de la justicia constitucional. De ser modificada, debiera serlo sólo en el

79 F. Rubio y M. Aragón, op. cit., págs. 836-838.

so «... si en el futuro se plantearan casos concretos que permitieran apreciar nuevos matices en orden a justificar la oposición -o la disconformidad- a la Constitución de alguno de los preceptos cuya inconstitucionalidad no se declara ahora, el juez o tribunal correspondiente podría promover la cuestión de inconstitucionalidad con relación al precepto que le suscitara la duda, de acuerdo con lo dispuesto en el art. 38.2 de la ley orgánica del Tribunal.» 
sentido de extender a las relaciones recurso-cuestión el régimen previsto por el artículo 38.2 para las relaciones entre recursos sucesivos.

Un tercer y último supuesto se verificaría en el caso de que se plantease cuestión de inconstitucionalidad sobre norma declarada conforme con la ley fundamental en sentencia que venía a responder a una cuestión anterior. La LOTC no le ofrece disposición específica. En su generalidad, el artículo 38.1 podría englobarlo, empujando a su inadmisibilidad. Huyendo de este resultado $\mathrm{y}$ buscando el opuesto, hay quienes recomiendan leer exclusivamente el número 3 del mismo artículo. Realmente, lo más lógico es atribuir a la sentencia desestimatoria en una cuestión de inconstitucionalidad efectos idénticos a los de la sentencia desestimatoria en un recurso de inconstitucionalidad y, por tanto, extender a este supuesto la regulación que haya de darse al examinado en el párrafo precedente. Lo dispuesto por el artículo 50.2.c, en relación con el recurso de amparo, apoyaría una solución en esta línea ${ }^{81}$.

${ }^{81}$ Véase en este sentido L. Pastor, Aplicación de la ley y control de constitucionalidad, en El Tribunal Constitucional, cit., vol. III, págs. 2027-2028. 